\title{
De toekomstige arbeidsmarktpositie van het Hoger Onderwijs
}

Citation for published version (APA):

de Grip, A., Jacobs, A. J. C. M., \& Smit, L. (2000). De toekomstige arbeidsmarktpositie van het Hoger Onderwijs. Researchcentrum voor Onderwijs en Arbeidsmarkt, Faculteit der Economische

Wetenschappen. ROA Reports No. 8 https://doi.org/10.26481/umarep.2000008

Document status and date:

Published: 01/01/2000

DOI:

10.26481/umarep.2000008

Document Version:

Publisher's PDF, also known as Version of record

\section{Please check the document version of this publication:}

- A submitted manuscript is the version of the article upon submission and before peer-review. There can be important differences between the submitted version and the official published version of record.

People interested in the research are advised to contact the author for the final version of the publication, or visit the DOI to the publisher's website.

- The final author version and the galley proof are versions of the publication after peer review.

- The final published version features the final layout of the paper including the volume, issue and page numbers.

Link to publication

\footnotetext{
General rights rights.

- You may freely distribute the URL identifying the publication in the public portal. please follow below link for the End User Agreement:

www.umlib.nl/taverne-license

Take down policy

If you believe that this document breaches copyright please contact us at:

repository@maastrichtuniversity.nl

providing details and we will investigate your claim.
}

Copyright and moral rights for the publications made accessible in the public portal are retained by the authors and/or other copyright owners and it is a condition of accessing publications that users recognise and abide by the legal requirements associated with these

- Users may download and print one copy of any publication from the public portal for the purpose of private study or research.

- You may not further distribute the material or use it for any profit-making activity or commercial gain

If the publication is distributed under the terms of Article $25 \mathrm{fa}$ of the Dutch Copyright Act, indicated by the "Taverne" license above, 


\section{De toekomstige arbeidsmarktpositie van het Hoger Onderwijs}

ROA-R-2000/8
A. de Grip
A. Jacobs
L. Smit

Researchcentrum voor Onderwijs en Arbeidsmarkt

Faculteit der Economische Wetenschappen en Bedrijfskunde Universiteit Maastricht

Maastricht, september 2000 
ISBN 90-5321-290-6

Sec00.035/AdG 


\section{Inhoud}

Pagina

Voorwoord

1 Inleiding 1

2 Toekomstige knelpunten in de personeelsvoorziening voor hoger opgeleiden

3 De vraag naar docenten in het Hoger Onderwijs

3.1 De vraag naar docenten als gevolg van de ontwikkelingen in de studentaantallen

3.2 De vraag naar docenten als gevolg van de vergrijzing

4 Concurrentiepositie Hoger Onderwijs $\quad 17$

$\begin{array}{ll}4.1 \text { Inleiding } & 17\end{array}$

4.2 Beloning 20

4.3 Werkzekerheid 21

4.4 Kwaliteit van het werk $\quad 22$

4.5 Tevredenheid recent afgestudeerden 23

4.6 Belangrijke baankenmerken $\quad 24$

4.7 Positieve of negatieve keuze? 26

5 Besluit 29

5.1 Conclusie $\quad 29$

5.2 Beleidsimplicaties 31

Bijlage: Achtergrondtabellen 33 



\section{Voorwoord}

Docenten en ander onderwijzend personeel zijn cruciaal voor de kwaliteit van het (hoger) onderwijs. Er zullen weinigen zijn die deze stelling bestrijden. Tegelijkertijd zijn er, voor wie prognoses van de arbeidsmarktontwikkelingen beziet, aanzienlijke knelpunten te verwachten bij met name de werving van hoger opgeleiden. Aangezien er voornamelijk universitair opgeleiden als docent werzaam zijn in het hoger onderwijs, betekent dit dat hogescholen en universiteiten in toenemende mate met problemen op dit gebied te kampen kunnen krijgen. Juist gezien de centrale positie die docenten in het hoger onderwijs vervullen voor de kennisoverdracht binnen de instellingen én in onze samenleving, is een tekort aan docenten in deze sector zeer ernstig.

Tegen deze achtergrond heeft de Inspectie Hoger Onderwijs het ROA in 1999 gevraagd een empirische verkenning te maken van deze problematiek. Cijfers, analyses, pogingen tot verklaringen en suggesties voor de aanpak van de problematiek hebben de ROA-onderzoekers in dit rapport geordend.

Ik spreek, gezien de relevantie van de aangesneden problematiek, de hoop uit dat dit (technisch) rapport degenen die bij deze problematiek betrokken zijn, kan helpen bij hun eigen analyses en strategieën hoe het vraagstuk op effectieve wijze aan te pakken.

Utrecht, oktober 2000

Prof. dr. Frans L. Leeuw

Hoofdinspecteur, Inspectie van het Onderwijs 



\section{Inleiding}

Het zicht op de knelpunten op de arbeidsmarkt waarmee de instellingen voor Hoger Onderwijs (hogescholen en universiteiten) de komende jaren bij de werving van docenten ${ }^{1}$ geconfronteerd zullen worden is momenteel onvoldoende aanwezig. Uit prognoses van de verwachte arbeidsmarktontwikkelingen verbijzonderd naar opleidingsniveau blijkt, dat er met name voor hoger opgeleiden grote knelpunten in de personeelsvoorziening worden verwacht ${ }^{2}$. Daar er voornamelijk universitair opgeleiden als docent werkzaam zijn in het Hoger Onderwijs betekent dit dat hogescholen en universiteiten bij de werving van personeel in toenemende mate met problemen te kampen kunnen krijgen. Dit geldt temeer daar het Hoger Onderwijs vanwege de relatief grote groep oudere docenten die de komende jaren de arbeidsmarkt zal verlaten, in toenemende mate nieuw personeel moet aantrekken om in de vervangingsvraag te voorzien. Bovendien kan het voorkomen dat het aantal studenten in het Hoger Onderwijs, na een stagnatie van de groei in de loop van de jaren negentig, de laatste jaren weer zal aantrekken. Ook dit kan leiden tot een toenemende vraag naar docenten.

Gezien de spilfunctie die de docenten in het Hoger Onderwijs vervullen voor de kennisoverdracht in de Nederlandse samenleving, is een tekort aan docenten in deze sector zeer zorgwekkend voor het toekomstige niveau van de onderwijskwaliteit. Dit kan derhalve een belangrijke hinderpaal vormen voor de gewenste voortgaande ontwikkeling van de Nederlandse samenleving in de richting van een kennisintensieve economie.

In de huidige samenleving is er in alle bedrijfssectoren vraag naar universitair opgeleiden. Het percentage werkenden met een WO-opleidingsachtergrond varieert echter aanzienlijk tussen de verschillende bedrijfssectoren. Circa ruim $7 \%$ van de werkende beroepsbevolking heeft een universitaire opleidingsachtergrond. De verschillen tussen de bedrijfssectoren zijn echter groot. Er zijn bedrijfssectoren waarin traditioneel vrijwel geen en bedrijfssectoren waarin traditioneel veel academisch opgeleiden werkzaam zijn. Tabel 1.1 presenteert, verbijzonderd naar bedrijfssector, het aantal werkenden met een universitaire opleidingsachtergrond in de verschillende bedrijfssectoren.

Uit de tabel blijkt dat er in de agrarische sectoren vrijwel geen academici werkzaam zijn. Daarentegen is bijna $20 \%$ van de werkenden in het Onderwijs universitair opgeleid. In het Hoger Onderwijs ligt het werkgelegenheidsaandeel van de universitair opgeleiden nog veel hoger. Meer dan de helft van de werkenden in deze sector heeft een WO-opleiding. Ook in het Bankwezen, de Zakelijke dienstvertening,

1. In dit rapport spreken we gemakshalve van docenten. Bij universiteiten gaat het hier om het gehele wetenschappelijke personeel.

2. Zie het rapport De Arbeidsmarkt naar Opleiding en Beroep, ROA-R-1999/8 en de bijbehorende Statistische Bijlage ROA-R-1999/8b, Maastricht 1999. 
Gezondheidszorg, en de Overige kwartaire diensten is meer dan $10 \%$ van de werkenden universitair opgeleid. In de industriële sector is het percentage universitair opgeleiden veel lager. De chemische industrie vormt hierop een uitzondering, op ruime afstand gevolgd door de elektrotechniek industrie en de grafische industrie. In deze laatste sector werken de universitair opgeleiden vooral in de journalistieke functies.

Tabel 1.1

Werkenden met WO-opleidingsachtergrond per bedriffssector (in procenten van het totaal aantal werkenden in de sector), gemiddelde 1997-1998

\begin{tabular}{|c|c|c|}
\hline & Aantal & $\%$ \\
\hline $\begin{array}{l}\text { Tuinbouw } \\
\text { Veehouderij } \\
\text { Akkerbouw, bosbouw en visserij } \\
\text { Vlees- en visverwerking } \\
\text { Overige voedingsproducten } \\
\text { Drank en tabaksproducten } \\
\text { Basischemie } \\
\text { Eindproducten chemie } \\
\text { Kunststofverwerking } \\
\text { Basismetaal } \\
\text { Metaalproducten } \\
\text { Machine-industrie } \\
\text { Elektrotechniek } \\
\text { Transportmiddelen } \\
\text { Textiel } \\
\text { Hout-en bouwmaterialen } \\
\text { Papier } \\
\text { Grafische industrie } \\
\text { Energie } \\
\text { Bouw } \\
\text { Exploitatie van onroerend goed } \\
\text { Handel } \\
\text { Scheeps- en luchtvaart } \\
\text { Weg- en railvervoer } \\
\text { Communicatie } \\
\text { Bankwezen } \\
\text { Verzekeringswezen } \\
\text { Horeca } \\
\text { Zakelijke dienstverlening } \\
\text { Overige commerciële dienstverlening } \\
\text { Gezondheidszorg } \\
\text { Overige kwartaire diensten } \\
\text { Onderwijs } \\
\text { Hoger Onderwijs } \\
\text { Overheid } \\
\text { Overig }\end{array}$ & $\begin{array}{r}- \\
- \\
2.500 \\
- \\
3.300 \\
4.500 \\
- \\
- \\
3.100 \\
6.100 \\
- \\
- \\
- \\
5.700 \\
3.200 \\
2.600 \\
3.900 \\
21.000 \\
2.400 \\
4.800 \\
4.800 \\
18.700 \\
9.000 \\
108.900 \\
5.700 \\
97.800 \\
31.000 \\
80.000 \\
47.500 \\
41.500 \\
7.300\end{array}$ & $\begin{array}{r}0,4 \\
0,4 \\
- \\
2,3 \\
3,6 \\
7,7 \\
9,0 \\
2,1 \\
0,3 \\
3,4 \\
5,7 \\
1,6 \\
- \\
5 \\
5,8 \\
5,0 \\
0,6 \\
8,0 \\
2,1 \\
5,2 \\
1,9 \\
4,7 \\
12,8 \\
8,9 \\
0,5 \\
17,2 \\
3,7 \\
11,1 \\
19,9 \\
19,2 \\
51,9 \\
8,0 \\
5,2\end{array}$ \\
\hline Totaal & 473.600 & 7,3 \\
\hline
\end{tabular}

Bron: CBS/ROA

"-" Aantall werkenden met WO-opleidingsachtergrond is lager dan publicatiegrens van 2.500

Van de in totaal circa $\mathbf{4 7 5 . 0 0 0}$ universitair opgeleiden die in Nederland werkzaam zijn, werken er circa 80.000 in het onderwijs. Dit is een marktaandeel van $16,9 \%$. Van deze 80.000 zijn er circa 47.600 werkzaam in het Hoger Onderwijs. Dit is dus 
goed voor een marktaandeel van 10,1\%. Tien procent van alle WO-opgeleiden vindt dus emplooi in het Hoger Onderwijs.

Tabel 1.2 presenteert de belangrijkste beroepsgroepen in het Hoger Onderwijs. In totaal telt het Hoger Onderwijs ruim 90.000 werknemers. Dat is circa $19,3 \%$ van het totaal aantal werkenden in de sector Onderwijs. Ruim $35 \%$ van hen is werkzaam als docent. Daarbij zijn beroepsgroepen als 'natuurwetenschappers' en artsen buiten beschouwing gelaten.

Tabel 1.2

Belangrijkste beroepen in het Hoger Onderwijs 1997/1998

Aantal werknemers

$\begin{array}{lr}\text { Docenten exacte, medische en verzorgende vakken (1e graads) } & 6.200 \\ \text { Docenten economisch-administratieve vakken (1e graads) } & 5.400 \\ \text { Docenten letteren (1e graads) } & 4.500 \\ \text { Docenten sociale vakken (1e graads) } & 3.700 \\ \text { Overige docenten } & 12.600 \\ \text { Managers } & 3.000 \\ \text { Natuunwetenschappers } & 3.300 \\ \text { Artsen } & 2.500 \\ \text { Boekhouders en secretaresses } & 8.600 \\ & \\ \text { Overig } & 10.700 \\ \text { Totaal } & \\ \end{array}$

Bron: CBS/ ROA

N.B. De beroepsgroepen met minder dan 2.500 werkenden in het Hoger Onderwijs zijn niet vermeld

Tabel 1.3 geeft een overzicht van de opleidingsachtergrond van de WO'ers die werkzaam zijn in het Hoger Onderwijs. De werkenden met een opleidingsachtergrond WO sociale wetenschappen, en WO wiskunde en natuunwetenschappen blijken het sterkst vertegenwoordigd in het Hoger Onderwijs. In het Hoger Onderwijs werken ook ruim 6.000 mensen met een $\mathrm{HBO}$ leranenopleiding als opleidingsachtergrond. Waarschijnlijk zijn zij ook deels als docent werkzaam. Geconcludeerd kan echter worden dat het Hoger Onderwijs voornamelijk onder academisch opgeleiden haar docenten werft.

In dit rapport zal getracht worden een beeld te schetsen van de knelpunten in de personeelsvoorziening waarmee het Hoger Onderwijs de komende jaren naar verwachting te maken zal krijgen. Eerst zal in hoofdstuk 2 de algemene arbeidsmarktsituatie voor hoger opgeleiden kort worden geschetst. Daarbij zal worden ingegaan op de te verwachten knelpunten in de personeelsvoorzienig voor de diverse WO opleidingstypen en de achterliggende oorzaken. Hierbij komen achtereenvolgens de vervangingsvraag, de uitbreidingsvraag en de arbeidsmarktinstroom van WO'ers aan de orde. Daarna wordt in hoofdstuk 3 nader ingegaan op de vraag naar docenten in het hoger onderwijs. Daarbij zal een onderscheid worden gemaakt tussen de vraag naar docenten als gevolg van de vergrijzing in het Hoger Onderwijs 
(de vervangingsbehoefte) en de vraag naar docenten als gevolg van de ontwikkelingen in de studentaantallen (de uitbreidingsvraag). In hoofdstuk 4 zal de concurrentiepositie van de instellingen voor het hoger onderwijs op de arbeidsmarkt centraal staan. Hierbij wordt bekeken in hoeverre het Hoger Onderwijs moet concurreren met andere bedrijfssectoren om gekwalificeerd personeel te werven. In hoofdstuk 5 wordt ingegaan op de mogelijkheden om de personeeltekorten in het Hoger Onderwijs te verminderen. Ten slotte zal in dit laatste hoofdstuk een aantal concluderende opmerkingen worden gemaakt.

Tabel 1.3

Opleidingsachtergrond van universitair opgeleiden werkzaam in het Hoger Onderwijs $1997 / 1998$

Aantal werknemers

Taal en cultuur

WO letteren

6.600

WO sociale wetenschappen

11.000

Natuur

WO wiskunde en natuurwetenschappen

12.600

Economie

WO econom(etr)ie

Recht

WO rechten en bestuurskunde

WO overig

11.400

Totaal

91.500

Bron: CBS/ROA

N.B. De opleidingstypen in de bedrijfssector Hoger Onderwijs met minder dan 2.500 werknemers zijn niet vermeld 


\section{Toekomstige knelpunten in de personeelsvoorziening voor hoger opgeleiden}

Zoals reeds in de inleiding is opgemerkt, werven de instellingen voor het Hoger Onderwijs hun docenten voornamelijk onder universitair opgeleiden. We zullen ons daarom hier beperken tot het in kaart brengen van de knelpunten op deze segmenten van de arbeidsmarkt. In het ROA-rapport De arbeidsmarkt naar opleiding en beroep tot 2004 wordt op basis van de verwachte vraag- en aanbodontwikkelingen in de periode 1999-2004 een indicatie gegeven van de toekomstige knelpunten in de personeelsvoorziening, verbijzonderd naar opleidings- type ${ }^{3}$.

Tabel 2.1

Indicator toekomstige knelpunten in de personeelsvoorziening (ITKP) in 2004

\begin{tabular}{|c|c|c|}
\hline Opleidingstype & ITKP & Typering knelpunten \\
\hline $\begin{array}{l}\text { Landbouw en natuurlijke omgeving } \\
\text { WO landbouw en milieukunde }\end{array}$ & 1,01 & enige \\
\hline $\begin{array}{l}\text { Natuur } \\
\text { WO wiskunde en natuurwetenschappen } \\
\text { WO farmacie }\end{array}$ & $\begin{array}{l}0,97 \\
1,02\end{array}$ & $\begin{array}{l}\text { groot } \\
\text { enige }\end{array}$ \\
\hline $\begin{array}{l}\text { Techniek } \\
\text { WO bouwkunde } \\
\text { WO civiele techniek } \\
\text { WO werktuigbouwkunde } \\
\text { WO elektrotechniek } \\
\text { WO informatica en bestuurlijke informatiekunde }\end{array}$ & $\begin{array}{l}0,90 \\
0,86 \\
0,96 \\
0,88 \\
0,76\end{array}$ & $\begin{array}{l}\text { groot } \\
\text { groot } \\
\text { groot } \\
\text { groot } \\
\text { zeer groot }\end{array}$ \\
\hline $\begin{array}{l}\text { Gezondheid } \\
\text { WO (dier)geneeskunde } \\
\text { WO tandheelkunde }\end{array}$ & $\begin{array}{l}0,97 \\
0,87\end{array}$ & $\begin{array}{l}\text { groot } \\
\text { groot }\end{array}$ \\
\hline $\begin{array}{l}\text { Economie } \\
\text { WO econom(etr)ie } \\
\text { WO bedrijfskunde } \\
\text { WO accountancy en belastingen }\end{array}$ & $\begin{array}{l}0,81 \\
0,85 \\
0,71\end{array}$ & $\begin{array}{l}\text { zeer groot } \\
\text { zeer groot } \\
\text { zeer groot }\end{array}$ \\
\hline $\begin{array}{l}\text { Recht } \\
\text { WO rechten en bestuurskunde }\end{array}$ & 0,95 & groot \\
\hline $\begin{array}{l}\text { Gedrag en maatschappij } \\
\text { WO sociale wetenschappen }\end{array}$ & 0,93 & groot \\
\hline $\begin{array}{l}\text { Taal en cultuur } \\
\text { WO letteren } \\
\text { WO theologie } \\
\text { WO kunstwetenschappen }\end{array}$ & $\begin{array}{l}0,93 \\
0,89 \\
1,11\end{array}$ & $\begin{array}{l}\text { groot } \\
\text { groot } \\
\text { vrijwel geen }\end{array}$ \\
\hline
\end{tabular}

\section{Bron: ROA}

Om de verwachte toekomstige wervingsproblemen voor de verschillende opleidingstypen in beeld te kunnen brengen, is een indicator van de toekomstige knel-

3. ROA, De Arbeidsmarkt naar Opleiding en Beroep, ROA-R-1999/8, Maastricht, 1999. 
punten in de personeelsvoorziening (ITKP) opgesteld. Wanneer de ITKP kleiner is dan 1,00 dan is de vraag groter dan het aanbod op het desbetreffende segment van de arbeidsmarkt. In dat geval is er sprake van grote knelpunten in de personeelsvoorziening. Is de ITKP zelfs kleiner of gelijk aan 0,85 dan wordt gesproken over zeer grote knelpunten in de personeeisvoorziening. Tabel 2.1 geeft een overzicht van de verwachte toekomstige knelpunten in de personeelsvoorziening voor de 18 onderscheiden opleidingstypen op WO-niveau.

Met uitzondering van de opleidingen WO landbouw en milieukunde, WO farmacie en WO kunstwetenschappen worden op de middellange termijn over de volle breedte van de arbeidsmarkt voor hoger opgeleiden grote knelpunten in de personeelsvoorziening verwacht. De grootste knelpunten worden verwacht voor de opleidingstypen:

- WO accountancy en belastingen;

- WO informatica en bestuurlijke informatiekunde;

- WO econom(etr)ie en WO bedrijfskunde.

Werkgevers die mensen moeten zien aan te trekken met een van deze opleidingsachtergronden zullen dan ook te maken krijgen met grote wervingsproblemen.

In het algemeen kunnen twee oorzaken ten grondslag liggen aan het ontstaan van knelpunten in de personeelsvoorziening op een bepaald arbeidsmarktsegment. De vraag naar mensen met een bepaalde opleidingsachtergrond kan relatief groot zijn, of het aanbod van nieuwkomers kan gering zijn. Bij de vraag naar mensen met een bepaaide opleidingsachtergrond kan een onderscheid worden gemaakt tussen de vervangingsvraag en de uitbreidingsvraag. De vervangingsvraag is de vraag naar nieuwe arbeidskrachten die ontstaat doordat de arbeidsplaatsen van werkenden die met pensioen gaan, arbeidsongeschikt worden of zich (tijdelijk) terugtrekken van de arbeidsmarkt, opnieuw moeten worden opgevuld. De uitbreidingsvraag betreft de vraag naar nieuwe arbeidskrachten die ontstaat door groei van de werkgelegenheid.

De gemiddelde jaarlijkse vervangingsbehoefte als percentage van het totaal aantal werkenden wordt voor de periode 1999-2004 geschat op 3,4\%. Op WO niveau bedraagt de jaarlijkse vervangingsbehoefte naar verwachting in deze periode slechts $2,9 \%$. Deze betrekkelijk lage vervangingsvraag is in belangrijke mate het gevolg van het relatief lage percentage oudere arbeidskrachten met een universitaire opleiding. Op dit punt zijn er echter duidelijke verschillen tussen de diverse wO opleidingstypen.

Tabel 2.2 geeft een overzicht van de opleidingstypen waarvoor de relatief grote vervangingsvraag de oorzaak kan zijn van toekomstige knelpunten in de personeelsvoorziening. Voor deze drie opleidingen wordt voor de komende vijf jaar een grote vervangingsbehoefte voorspeld. Dit geeft aan dat werknemers met een van deze opleidingsachtergronden in het algemeen ouder zijn dan de werkenden met een andere WO-opleidingsachtergrond. De grote knelpunten die voor deze opleidingen worden verwacht, vinden dus mede hun oorzaak in de grote vervangingsbehoefte. 
Tabel 2.2

Verwachte vervangingsvraag voor WO opleidingstypen waarvoor in de periode 1999-2004 een relatief grote jaarlijkse vervangingsbehoefte wordt verwacht

\begin{tabular}{llcc}
\hline Opleidingstype & Aantal & $\begin{array}{c}\text { Gemiddeld } \\
\text { jaarlijks } \\
\%\end{array}$ & Typering \\
\hline Techniek & 7.300 & 2,7 & hoog \\
WO bouwkunde & 2.000 & 4,4 & hoog \\
WO civiele techniek & 1.700 & 4,4 & hoog \\
Gezondheid & 8.600 & 2,9 & 4,2 \\
WO tandheelkunde & 1.400 & &
\end{tabular}

Bron: ROA

Een andere oorzaak voor de verwachte grote toekomstige knelpunten in de personeelsvoorziening kan liggen in een relatief grote uitbreidingsvraag. Voor de periode 1999-2004 wordt op basis van het zogenoemde 'behoedzame scenario' van het Centraal Planbureau voor de komende jaren uitgegaan van een gemiddelde jaarlijkse uitbreidingsvraag van $1,0 \%$ van de werkgelegenheid. Voor universitair opgeleiden ligt deze uitbreidingsvraag echter op een veel hoger niveau. De verwachte gemiddelde jaarlijkse werkgelegenheidsgroei voor opleidingen op WO niveau bedraagt maar liefst $2,7 \%$. Deze hoge werkgelegenheidsgroei voor universitair opgeleiden geeft aan dat de kwalificatie-eisen die werkgevers stellen op een steeds hoger niveau komen te liggen vanwege de snelle technologische en organisatorische veranderingen die in veel sectoren plaatsvinden (zie ook ROA, 1999). Door deze steeds hogere opleidingseisen dient het Hoger Onderwijs bij de werving van hoger opgeleiden ook met steeds meer bedrijfssectoren te concurreren. In hoofdstuk 4 zal hierop worden teruggekomen.

Tabel 2.3

WO opleidingstypen waarvoor in de periode 1999-2004 een relatief erg hoge jaarlijkse uitbreidingsvraag wordt verwacht

\begin{tabular}{lccc}
\hline Opleidingstype & Aantal & $\begin{array}{c}\text { Gemiddeld } \\
\text { jaarlijks } \\
\%\end{array}$ & Typering \\
\hline Techniek & 6.200 & 2,3 & erg hoog \\
WO informatica en bestuurlijke & 4.900 & 8,6 & \\
informatiekunde & & & erg hoog \\
Economie & 34.300 & 6,6 & erg hoog \\
WO econom(etr)ie & 17.500 & 6,6 & erg hoog \\
WO accountancy en belastingen & 6.700 & 7,1 & erg hoog \\
WO bedrijfsunde & 10.000 & 7,3 & 3,7 \\
Gedrag en Maatschappij & 17.300 & 3,7 & \\
WO sociale wetenschappen & 17.300 & 3,7 & \\
\hline B ROA ROA & & &
\end{tabular}


Bij een aantal WO-opleidingstypen ligt de verwachte uitbreidingsvraag op een veel hoger niveau. Tabel 2.3 geeft een overzicht van de opleidingstypen met een relatief hoge jaarlijkse uitbreidingsvraag. Voor deze opleidingen wordt voor de komende vijf jaar een erg hoge uitbreidingsvraag verwacht. Dit geldt met name voor de informatici en de economen. Deze hoge uitbreidingsvraag is op deze arbeidsmarktsegmenten een belangrijke oorzaak van de verwachte wervingsproblemen.

Bij een viertal andere opleidingen zijn de verwachte knelpunten in de personeelsvoorziening vooral toe te schrijven aan de relatief lage arbeidsmarktinstroom van afgestudeerden (zie tabel 2.4).

Tabel 2.4

WO opleidingstypen waarvoor in de periode 1999-2004 een relatief lage jaarlijkse arbeidsmarktinstroom van afgestudeerden wordt verwacht

\begin{tabular}{|c|c|c|c|}
\hline Opleidingstype & Aantal & $\begin{array}{c}\text { Gemiddeld } \\
\text { jaarlijks } \\
\%\end{array}$ & Typering \\
\hline $\begin{array}{l}\text { Techniek } \\
\text { WO elektrotechniek }\end{array}$ & $\begin{array}{r}10.800 \\
1.500\end{array}$ & $\begin{array}{l}4,0 \\
3,0\end{array}$ & laag \\
\hline $\begin{array}{l}\text { Gezondheid } \\
\text { WO tandheelkunde } \\
\text { WO (dier)geneeskunde }\end{array}$ & $\begin{array}{r}7.400 \\
800 \\
6.600\end{array}$ & $\begin{array}{l}2,5 \\
2,5 \\
2,7\end{array}$ & $\begin{array}{l}\text { laag } \\
\text { laag }\end{array}$ \\
\hline $\begin{array}{l}\text { Taal en culfuur } \\
\text { WO theologie }\end{array}$ & $\begin{array}{r}15.900 \\
700\end{array}$ & $\begin{array}{l}4,4 \\
1,7\end{array}$ & laag \\
\hline
\end{tabular}

Bron: ROA

Bij WO tandheelkunde is er daarbij zowel sprake van een hoge vervangingsvraag als een lage arbeidsmarktinstroom van nieuwkomers.

\section{Conclusie}

Met uitzondering van de opleidingen WO landbouw en milieukunde, WO farmacie en WO kunstwetenschappen worden voor alle WO opleidingstypen de komende jaren grote knelpunten in de personeelsvoorziening verwacht. Bij WO accountancy en belastingen, WO informatica en bestuurlijke informatiekunde, WO econom(etr)ie en WO bedrijfskunde kan zelfs gesproken worden van zeer grote knelpunten. Bij een aantal opleidingen zijn deze knelpunten voornamelijk toe te schrijven aan een sterke groei van de werkgelegenheid. Dit geldt vooral voor de informatici, economen en bedrijfskundigen. Bij enkele technische opleidingen en de opleiding tandheelkunde waar de vergrijzing veel verder is voortgeschreden dan bij andere WO-opleidingstypen, zijn de verwachte arbeidsmarktknelpunten vooral toe te schrijven aan de naar verwachting hoge vervangingsvraag. Bij WO elektrotechniek, WO theologie en de medische opleidingen zijn de verwachte knelpunten vooral het gevolg van de relatief lage arbeidsmarktinstroom van afgestudeerden. Met name bij de medische oplei- 
dingen is dit opmerkelijk, gezien de 'arbeidsmarkt fixus' die bij de toelating van deze opleidingen wordt gehanteerd. 
10 


\section{De vraag naar docenten in het Hoger Onderwijs}

\subsection{De vraag naar docenten als gevolg van de ontwikkelingen in de student- aantallen}

In dit hoofdstuk zullen de vervangingsbehoefte en de groei van de werkgelegenheid voor docerend personeel in het Hoger Onderwijs centraal staan. Op basis van de ontwikkelingen in studentenaantallen zal de werkgelegenheidsgroei in het Hoger Onderwijs worden beschouwd. Daarna wordt aan de hand van de leeftijdsopbouw van werknemers in het Hoger Onderwijs de vervangingsbehoefte van docenten in het Hoger Onderwijs verder verbijzonderd.

De uitbreidingsvraagprognoses die in het vorige hoofdstuk gepresenteerd zijn, geven slechts een globaal beeld van de werkgelegenheidsgroei voor universitair opgeleiden met een bepaalde opleidingsachtergrond. Om een indicatie te krijgen van de verwachte werkgelegenheidsontwikkeling voor docenten in het Hoger Onderwijs zal gebruik worden gemaakt van de beschikbare ramingen van de studentaantallen in het Hoger Onderwijs in combinatie met de student/docent ratio's.

\section{Hoger Beroepsonderwijs}

Uit de $\mathrm{HBO}$ managementinformatie ${ }^{4}$ blijkt dat er in het $\mathrm{HBO}$ de afgelopen jaren een verschuiving is opgetreden van docerend personeel naar ondersteunend personeel. Daardoor is de student/personeel ratio in de jaren 1995-'98 min of meer constant gebleven, terwijl de student/docent ratio licht is toegenomen ${ }^{5}$. Om een indicatie van de uitbreidingsvraag naar docenten in het $\mathrm{HBO}$ te geven relateren we de student/ docentratio van 1998 , een ratio van 18,0 aan de prognose van het verwachte aantal studenten volgens de Referentieraming 1999.

Tabel 3.1

Prognoses aantallen studenten en vraag naar docenten (fte's) in het HBO, 1999-2003

\begin{tabular}{lrrrrr}
\hline & 1999 & 2000 & 2001 & 2002 & 2003 \\
\hline Studenten & 244.000 & 244.600 & 234.100 & 232.600 & 234.100 \\
Docenten & 13.600 & 13.600 & 13.000 & 12.900 & 13.000 \\
\hline
\end{tabular}

Bron: Referentieraming 2000/ROA

* Op basis van student/docent ratio 1998

Uit de cijfers van tabel 3.4 blijkt dat na een lichte stijging van 13.300 in 1998 tot 13.600 in 1999, het verwachte aantal studenten in het Hoger Beroepsonderwijs in 2001 terug loopt en daarna min of meer constant zal blijven. Het aantal docenten zal

4. HBO-raad, HBO managementinformatie 1997, Onderweg met managementinformatie, Den Haag, 1999.

5. Zie ook Onderwijsversiag over het jaar 1998, Inspectie van het Onderwijs, Utrecht, 1999. 
na een kleine stijging daarom licht dalen en vervolgens op een constant niveau blijven. Wanneer er geen verandering optreedt in de tijdelijke aanstellingsomvang bedraagt de totale werkgelegenheid van docenten in het $\mathrm{HBO}$, gemeten in aantallen personen, in 2003 17.200. De werkgelegenheid zal de komende vijf jaar in totaal met $2,3 \%$ afnemen. Dat betekent een jaarlijkse daling van bijna $0,5 \%$. Het verwachte aantal te werven docenten zal als gevolg van deze daling in de werkgelegenheid alleen bepaald worden door de verwachte vervangingsvraag voor de komende jaren.

Recentelijk door de HBO-raad naar buiten gebrachte cijfers wijzen echter op een sterke toename van het aantal studenten in het HBO. Verwacht wordt dat er in 2004 330.000 studenten staan ingeschreven in het $\mathrm{HBO}$. In dit geval zou de werkgelegenheid voor docenten in het $\mathrm{HBO}$ enorm toenemen hetgeen de knelpunten in de personeelsvoorziening sterk zou vergroten.

\section{Wetenschappelijk Onderwijs}

In het WO is in de afgelopen jaren sprake van een krimpende werkgelegenheid voor het wetenschappelijk personeel ${ }^{6}$. Om de toekomstige uitbreidingsvraag te bepalen, wordt gebruik gemaakt van de student/docent ratio. In de jaren 1993 en 1994 bedraagt deze ratio nog 8,1 , daarna daalt de ratio naar 7,4 in $1998^{7}$. Om de werkgelegenheidsgroei voor de komende jaren te berekenen wordt de ratio van 1998 als basis genomen. Deze ratio ligt in het WO op een beduidend lager niveau dan in het $\mathrm{HBO}$. De verklaring hiervoor kan gezocht worden in het feit dat docenten naast hun taken in het onderwijs ook wetenschappelijk onderzoek verrichten.

Tabel 3.2 presenteert de geraamde studentaantallen voor de komende jaren en de, op basis van de student/docent ratio, verwachte aantallen benodigde docenten/ wetenschappelijk medewerkers in de jaren 1999-2003.

Tabel 3.2

Prognoses aantallen studenten en vraag naar docenten (fte's) in het WO, 1999-2003

\begin{tabular}{|c|c|c|c|c|c|}
\hline & 1999 & 2000 & 2001 & 2002 & 2003 \\
\hline $\begin{array}{l}\text { Studenten } \\
\text { Docenten }\end{array}$ & $\begin{array}{r}159.400 \\
21.500\end{array}$ & $\begin{array}{r}159.300 \\
21.500\end{array}$ & $\begin{array}{r}160.000 \\
21.600\end{array}$ & $\begin{array}{r}160.100 \\
21.600\end{array}$ & $\begin{array}{r}160.200 \\
21.600\end{array}$ \\
\hline
\end{tabular}

Bron: Referentieraming 2000/ROA

* Op basis van student/ docent ratio 1998

In tegenstelling tot het HBO kan voor het WO de komende jaren een lichte stijging van de werkgelegenheid worden verwacht. Uitgedrukt in personen zijn er, uitgaande van de gemiddelde aanstellingsomvang in 1998, de komende vijf jaar 26.700 docenten nodig. Dit betekent een uitbreidingsvraag van circa 300 personen.

6. Inspectie van het Onderwijs, Onderwijsverslag over het jaar 1998, Utrecht, 1999.

7. Zie ook Ondenwijsverslag over het jaar 1998, Inspectie van het Onderwijs, 1999. 
De lichte toename in het aantal studenten geldt echter niet voor alle WO- opleidingen. Onderverdeeld naar HOOP-sectoren laten de meeste sectoren zelfs een daling zien. De werkgelegenheidsgroei concentreert zich in de HOOP-sectoren Techniek en Economie. Vooral in deze sectoren zullen derhalve veel extra docenten moeten worden aangetrokken.

Tabel 3.3

Prognose vraag naar docenten (fte's) in het WO naar Hoop-sector, 1998-2003

\begin{tabular}{lrrrrr}
\hline & 1999 & 2000 & 2001 & 2002 & 2003 \\
\hline Landbouw & 800 & 800 & 700 & 700 & 700 \\
Natuur & 2.400 & 2.400 & 2.400 & 2.300 & 2.300 \\
Techniek & 3.400 & 3.400 & 3.400 & 3.400 & 3.500 \\
Gezondheid & 3.400 & 3.400 & 3.400 & 3.400 & 3.400 \\
Economie & 1.300 & 1.300 & 1.400 & 1.500 & 1.500 \\
Rechten & 900 & 900 & 900 & 900 & 800 \\
G\&M & 1.800 & 1.800 & 1.800 & 1.800 & 1.800 \\
T\&C & 1.500 & 1.400 & 1.400 & 1.400 & 1.400 \\
\hline
\end{tabular}

Bron: WOPI 1999, Referentieraming 2000/ROA

\subsection{De vraag naar docenten als gevolg van de vergrijzing}

\section{Hoger Beroepsonderwijs}

De hoogte van de vervangingsvraag is in belangrijke mate afhankelijk van de leeftijdsopbouw van de werkenden. Figuur 3.1 geeft een overzicht van de leeftijdsopbouw van het totaal aantal werkenden in het HBO in 1998. Maar liefst $33 \%$ van de werkenden in het HBO is $\mathbf{5 0}$ jaar of ouder. Dit betekent dat de vergrijzing van de werkenden hier veel verder is voortgeschreden dan in andere bedrijfssectoren ${ }^{8}$. Gemiddeld is slechts bijna $17 \%$ van de werkenden 50 jaar of ouder.

Het percentage werkenden dat 50 jaar of ouder is in de periode 1995-1998 gestaag toegenomen. Het personeel van het $\mathrm{HBO}$ is dus sterk aan het vergrijzen. Dit zal zich vertalen in een grote toekomstige vervangingsbehoefte.

Op basis van de zogenoemde cohort-change methode ${ }^{9}$ kan aan de hand van het netto-personeelsverloop in de periode 1994-1998 de vervangingsvraag worden bepaald. In de afgelopen vijf jaar betrof deze vervangingsbehoefte $9,0 \%$, wat neerkomt op een jaarlijks percentage van $1,7 \%^{10}$.

8. Uitzondering hierop zijn de eveneens sterk vergrijsde bedrijfssectoren veehouderij en akkerbouw, bosbouw en visserij met percentages van respectievelijk $29 \%$ en $33 \%$.

9. Zie E. Willems, en A. de Grip, Forecasting Replacement Demand by Occupation and Education, Intemational Joumal of Forecasting, Vol. 9, 1993, p. 173-185.

10. Het betreft hier zowel docerend als ondersteunend personeel, gemeten in fte's. 


\section{Leeftijdsopbouw personeelsformatie} (fte's) in HBO 1998

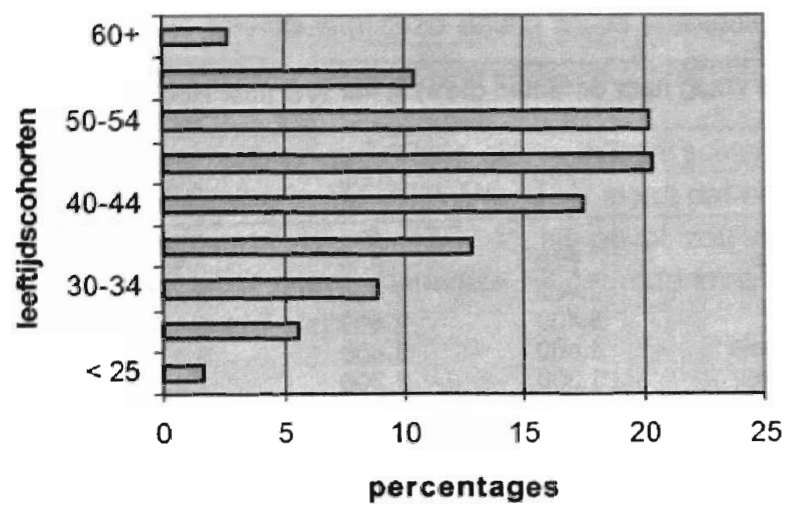

Bron: HBO Management informatie 1998

Voor de periode 1999-2003 wordt op basis van de cohort change methode in het HBO een vervangingsuraag voor docenten van $13,9 \%$ verwacht. Dit betekent dat jaarlijks $2,6 \%$ van de docenten vervangen dient te worden, wat neerkomt op circa 450 personen. De toekomstige vervangingsbehoefte ligt op een beduidend hoger niveau dan in de afgelopen jaren. Dit wijst er nogmaals op dat het personeelsbestand in het $\mathrm{HBO}$ sterk vergrijst.

De bovenstaande meetmethode levert echter een onderschatting op van de feitelijke vervangingsbehoefte omdat alleen de 'netto'-uitstroom wordt gemeten. Hierdoor wordt in feite alleen gekeken naar degenen die definitief de arbeidsmarkt verlaten vanwege (vervroegde) pensionering, arbeidsongeschiktheid e.d. Jongere werknemers die besluiten over te stappen naar een andere werkgever zullen echter ook vervangen moeten worden. De HBO-raad geeft in de HBO Management Informatie ${ }^{11}$ brutocijfers over de uitstroom van de werkenden in het HBO. Tabel 3.4 presenteert deze cijfers voor de jaren 1995-'97. Deze percentages liggen beduidend hoger dan de $1,7 \%$ op basis van de cohort-change methode. Dit wijst op een duidelijke personeelsuitstroom van jongere leeftijdssectore ${ }^{12}$. In 1997 is de uitstroom uit het HBO bovendien sterk toegenomen. In dat jaar diende bijna $8 \%$ van het personeelsbestand ververst te worden.

11. HBO-raad, HBO managementinformatie 1998, Den Haag, 1999.

12. In hoofdstuk 4 zal verder op de concurrentiepositie c.q. aantrekkelijkheid van het Hoger Onderwijs worden ingegaan. 


\begin{tabular}{lrrr}
\hline & $\begin{array}{r}1995 \\
\%\end{array}$ & $\begin{array}{r}1996 \\
\%\end{array}$ & $\begin{array}{r}1997 \\
\%\end{array}$ \\
\hline Uitstroom & 5,9 & 5,7 & 7,8 \\
\hline
\end{tabular}

\section{Bron: HBO-raad}

\section{De vervangingsbehoefte in het Wetenschappelijk Onderwijs}

Ook het personeelsbestand van de universiteiten is sterk aan hei vergrijzen ${ }^{13}$. In 1998 was maar liefst $27,4 \%$ van het totale wetenschappelijke personeel 50 jaar of ouder. In 1990 was dit nog maar $18 \%$. Bovendien blijkt dat het aandeel van de jongere leeftijdsgroepen blijft afnemen. Figuur 3.2 toont de leeftijdsopbouw van het wetenschappelijk personeel in het WO eind 1998. De leeftijdsopbouw is in het WO gelijker over de verschillende leeftijdsgroepen verdeeld dan in het HBO. Het grote aandeel van de 25-29 jarigen zal voor het merendeel uit aio's bestaan. Het percentage werkenden van 50 jaar en ouder bedraagt maar liefst $27 \%$. Deze sterke vergrijzing in het wetenschappelijk onderwijs en de bezorgdheid daarover wordt ook geîllustreerd in de toespraak die Rector Magnificus Nieuwenhuijzen Kruseman tijdens de Dies Natalis van de Universiteit Maastricht hield"4. "Met deze constatering ben ik aangekomen bij wat algemeen als de grootste bedreiging voor het universitair onderwijs en onderzoek wordt ervaren: De te verwachten tekorten aan wetenschappelijk personeel, deels door een krappe arbeidsmarktvoor academici en deels door de naderende uitstroom van een vergrijsde staf. De problemen waar het middelbaar onderwijs nu mee kampt, zijn voor het Hoger Onderwijs de problemen van morgen. Dat betekent dat er de komende 5 tot 10 jaar een grote vervangingsbehoefte van de wetenschappelijke staf ontstaat".

Ook voor het Wetenschappelijk Onderwijs is eerst op basis van de cohort-change methode de vervangingsbehoefte in de jaren 94-98 bepaald. In deze periode bedroeg de vervangingsvraag $13,1 \%$.

Dit betekent dat in deze periode jaarijks $2,5 \%$ van het wetenschappelijk personeel vervangen diende te worden. Voor de periode 1999-2004 wordt een vervangingsvraag van $15,1 \%$ verwacht; dat wil zeggen een jaarlijkse vervangingsbehoefte van $2,9 \%$, hetgeen neerkomt op circa 800 personen. Bij deze berekening is het aantal aio's dat uitstroomt buiten beschouwing gelaten. Door deze groep niet mee te nemen in de berekening van de toename van de vervangingsbehoefte kan een betere indicatie van de vervangingsbehoefte vanwege de vergrijzing van het doce-

13. VSNU, WO-Personeelsformatie 1999, Utrecht, 1999.

14. A.C. Nieuwenhuijzen Kruseman, Wetenschap blijt mensenwerk, Toespraak ter gelegenheid van de vierentwintigste Dies Natalis van de Universiteit Maastricht op 7 januari 2000. 
rend personeel worden verkregen. AlO's leveren echter een belangrijke bijdrage aan het verzorgen van het onderwijs. Als deze na hun promotie de universiteit verlaten zullen nieuwe mensen dienen te worden gezocht. Als ook met deze vervangingsbehoefte rekening wordt gehouden ligt de vervangingsvraag op een beduidend hoger niveau. In de jaren 1994-1998 bedroeg in dat geval de vervangingsvraag $18,1 \%$, wat neerkwam op $3,4 \%$ per jaar. Voor de komende vijf jaar zal de vervangingsbehoefte inclusief AIO's neerkomen op $25,8 \%$, wat een jaarlijks percentage van $4,7 \%$ inhoudt. Omgerekend in aantallen personen komt dat neer op circa 1.250 personen.

Figuur 3.2

\section{Leeftijdsopbouw wetenschappelijke personeelsformatie (fte's) 1998}

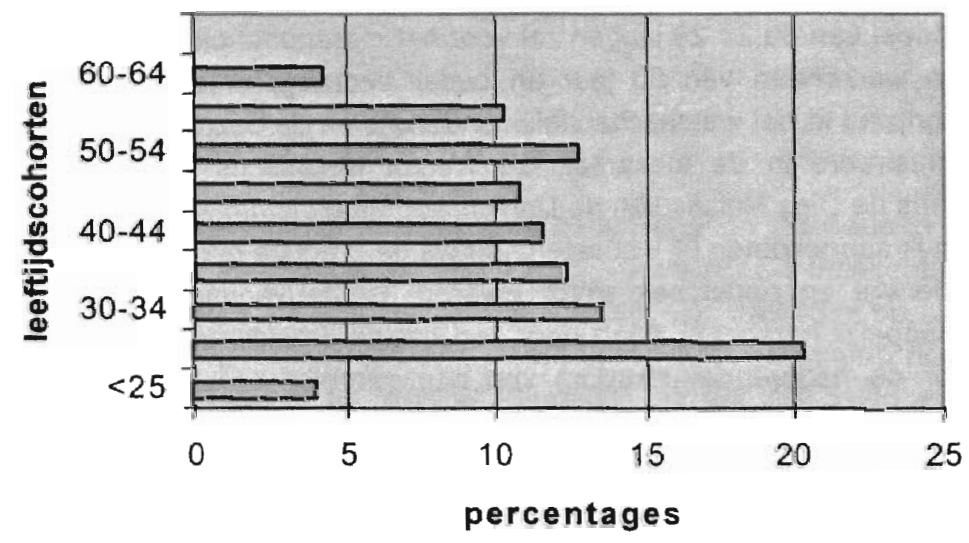

Bron: WOPI 1999 


\section{Concurrentiepositie Hoger Onderwijs}

\subsection{Inleiding}

Voor het Hoger Onderwijs is de arbeidsmarkt van recent afgestudeerde academici een belangrijk segment voor het aantrekken van nieuw personeel. In dit hoofdstuk zal de concurrentiepositie van de instellingen voor het Hoger Onderwijs op dit marktsegment nader worden belicht. Hierbij staat de aantrekkelijkheid van het werken in het Hoger Onderwijs vanuit het perspectief van recent afgestudeerde academici centraal ${ }^{15}$. De aantrekkelijkheid van het werken in het Hoger Onderwijs wordt in dit hoofdstuk vanuit vier invalshoeken bekeken:

- beloning;

- werkzekerheid;

- kwaliteit van het werk;

- tevredenheid met huidige functie.

Door te kijken hoe het werken in het Hoger Onderwijs op deze punten afsteekt tegen het werken in andere bedrijfssectoren kan een sterkte-zwakte profiel van de concurrentiekracht van de sector worden gemaakt.

Bij de beloning wordt gekeken naar de bruto uurlonen en de bruto maandlonen. De werkzekerheid wordt geïndiceerd door het percentage afgestudeerden met een flexibele aanstelling. De kwaliteit van het werk wordt vanuit twee invalshoeken belicht:

- het percentage afgestudeerden werkzaam op het eigen niveau;

- het percentage afgestudeerden werkzaam in eigen of daaraan verwante richting;

- het percentage afgestudeerden dat de aansluiting tussen opleiding en werk voldoende tot goed vindt.

In aanvulling hierop wordt gekeken naar een aantal subjectieve indicatoren die betrekking hebben op de tevredenheid met de huidige functie. Ten slotte wordt nagegaan in hoeverre de instellingen voor het Hoger Onderwijs er in slagen de voor hen meest geschikte kandidaten te werven door te kijken in hoeverre de recent afgestudeerden die men werf slechts kortdurig werkloos zijn geweest.

Voordat hierop wordt ingegaan wordt eerst in figuur 4.1 een overzicht gegeven van de marktaandelen van de verschillende bedrijfssectoren waarin recent afgestudeerde academici werkzaam zijn. De figuur laat zien dat $9 \%$ van de afgestudeerde academici van het academisch jaar 1996/1997 in het Hoger Onderwijs is gaan werken. Met name de zakelijke dienstverlening, met een marktaandeel van maar

15. De data zijn afkomstig uit het door het ROA ontwikkelde Schoolverlaters Informatie Systeem (SIS). De hier gepresenteerde cijfers hebben betrekking op de WO-Monitor. Het gaat hier om onderzoek dat is gehouden in het najaar van 1998 en betreft de afgestudeerden in het WO van het studiejaar 1996/1997. 
liefst bijna $50 \%$ en de kwartaire sector (exclusief het Hoger Onderwijs) blijken het grootste aantal afgestudeerden aan te trekken. Van de werkenden in het Hoger Onderwijs heeft meer dan de helft een aanstelling als AIO/OIO. Eerder in dit rapport is reeds vastgesteld dat het marktaandeel van het Hoger Onderwijs voor de totale populatie academici ruim $10 \%$ bedraagt. Te meer daar een (aanzienlijk) deel van degenen die op dit moment een ÂO/OIO-plaats hebben daarna waarschijnlijk buiten het Hoger Onderwijs zal gaan werken, is het marktaandeel van het Hoger Onderwijs op de arbeidsmarkt van recent afgestudeerden relatief laag te noemen.

\section{Figuur 4.1}

Sectoren waarin recent afgestudeerde WO-ers werkzaam zijn, 1998
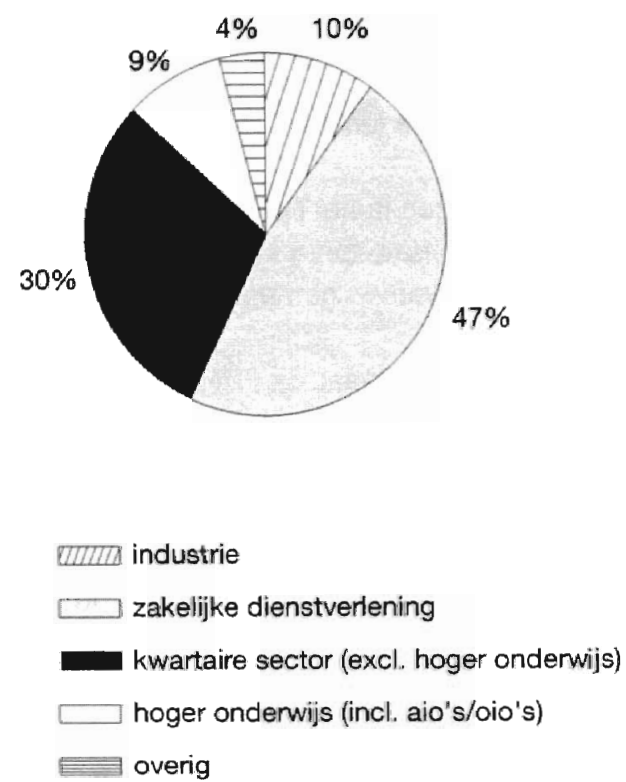

Figuur $\mathbf{4 . 2}$ laat zien dat het marktaandeel van het Hoger Onderwijs bij de verschillende studierichtingen sterk uiteenloopt. Het Hoger Onderwijs bezit met name een groot marktaandeel van $27 \%$ onder degenen met een opleidingsachtergrond WO natuur. Ook bij de richtingen WO techniek en WO landbouw en natuurlijke omgeving is het marktaandeel van de instellingen van het Hoger Onderwijs met respectievelijk $11 \%$ en $17 \%$, relatief hoog. Voor geen enkele studierichting heeft het Hoger Onderwijs het grootste marktaandeel. De grootste concurrent is, zoals reeds werd aangegeven, de zakelijke dienstverlening. De zakelijke dienstverlening heeft met name een zeer groot marktaandeel op de arbeidsmarkt voor economen, juristen en technici. Van de medici werkt bijna $90 \%$ in de kwartaire sector (waaronder de gezondheidszorg). Ook bij WO taal \& cultuur en WO gedrag en maatschappij heeft de kwartaire sector het grootste marktaandeel. 
Figuur 4.2

Marktaandeel hoger onderwijs onder recent afgestudeerde WO-ers naar opleidingsachtergrond, 1998
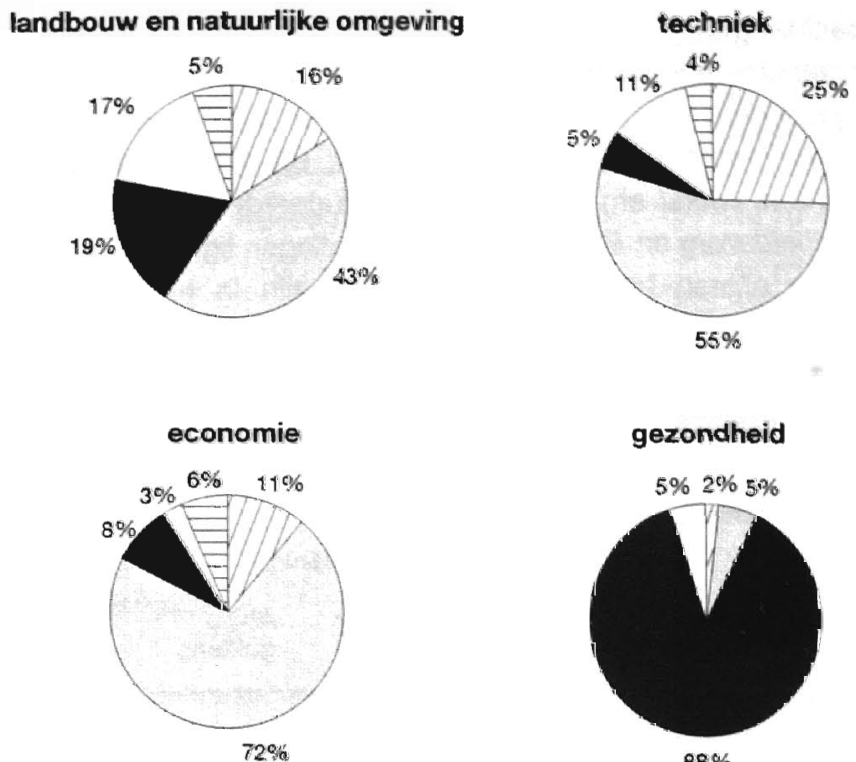

gedrag \& maatschappij

$$
\text { gezondheid }
$$

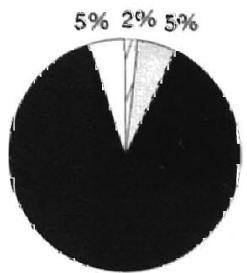

$88 \%$

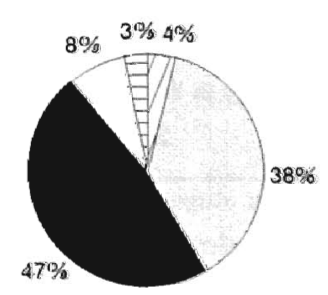

taal \& cultuur
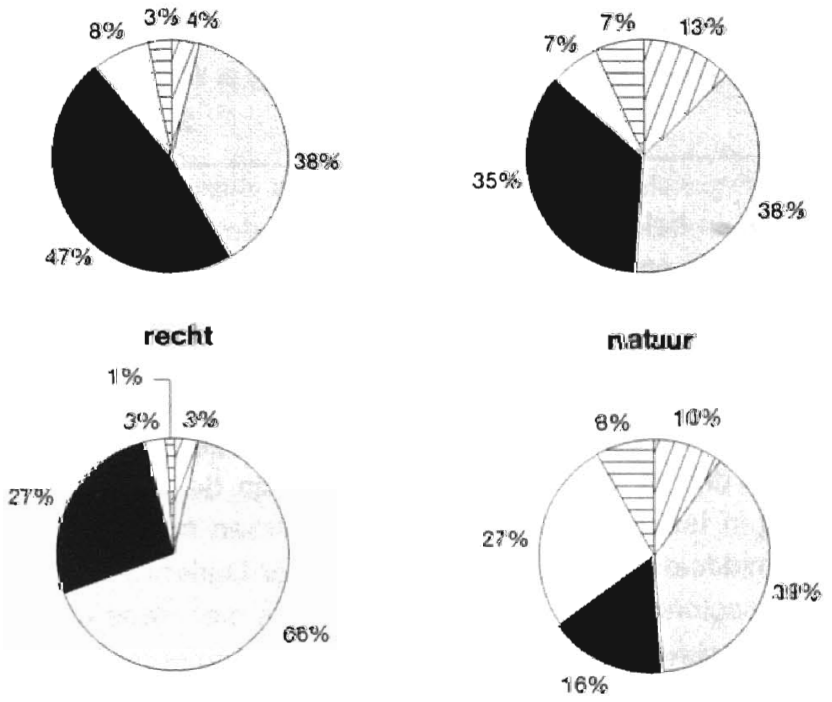

WIIID industrie

$\square$ zakelijke dienstverlening

kwartaire sector (excl. hoger onderwijs)

hoger onderwijs (incl. aio's/oio's)

overig 


\subsection{Beloning}

Tabel 4.1 geeft een overzicht van de gemiddelde bruto maandlonen van WO-ers naar opleidingsachtergrond. Uit de tabel blijkt direct dat niet alleen AIO's/OIO's, maar ook de universitair opgeleiden met een andere functie in het Hoger Onderwijs (bijv. toegevoegd docent of onderzoeker), beduidend minder verdienen dan hun jaargenoten die werkzaam zijn in andere sectoren. Dit geldt voor alle studierichtingen. Het verschil is vooral erg groot voor afgestudeerden in de HOOP-sectoren Techniek, Gezondheidszorg en Recht. Bij deze opleidingen ligt het gemiddelde bruto maandloon van de afgestudeerden die werkzaam zijn in het Hoger Onderwijs (exclusief de AlO's) meer dan 1.000 gulden lager dan in de andere sectoren.

Tabel 4.1

Gemiddelde bruto maandionen van recent afgestudeerde WO-ers naar opleidingsachtergrond, 1998

\begin{tabular}{|c|c|c|c|}
\hline \multirow[t]{2}{*}{ Opleiding } & \multicolumn{2}{|c|}{ Hoger onderwijs } & \multirow{2}{*}{$\begin{array}{c}\text { Overige sectoren } \\
\text { guldens }\end{array}$} \\
\hline & $\begin{array}{l}\text { excl. AlO's } \\
\text { guldens }\end{array}$ & $\begin{array}{l}\text { AlO's } \\
\text { guldens }\end{array}$ & \\
\hline $\begin{array}{l}\text { Landbouw en natuurlijke omgeving } \\
\text { Techniek } \\
\text { Economie } \\
\text { Gezondheid } \\
\text { Gedrag en maatschappij } \\
\text { Taal en cultuur } \\
\text { Recht } \\
\text { Natuur }\end{array}$ & $\begin{array}{l}3.436 \\
3.383 \\
3.841 \\
3.636 \\
3.509 \\
2.857 \\
3.534 \\
3.664\end{array}$ & $\begin{array}{l}2.418 \\
2.888 \\
2.545 \\
2.380 \\
2.359 \\
2.202 \\
2.216 \\
2.343\end{array}$ & $\begin{array}{l}3.887 \\
4.534 \\
4.627 \\
5.012 \\
3.885 \\
3.615 \\
4.583 \\
4.154\end{array}$ \\
\hline Totaal & 3.440 & 2.456 & 4.317 \\
\hline
\end{tabular}

Dit enorme verschil in beloning kan echter voor een deel verklaard worden doordat in het Hoger Onderwijs een groter aantal mensen in deeltijd werkt dan in de andere bedrijfssectoren. Om hiervoor te corrigeren zijn de opgegeven bruto maandlonen gedeeld door het aantal (contractuele) uren dat men werkzaam. is. De op deze wijze berekende gemiddelde bruto uurlonen zijn weergegeven in tabel 4.2. De tabel laat zien dat ook na een correctie voor deeltijdwerk de beloning in het Hoger Onderwijs een stuk lager ligt dan in de andere sectoren, al zijn de beloningsverschillen wel minder groot dan in tabel 4.1. Voor de afgestudeerden met een opleiding Taal \& Cultuur is het gemiddelde bruto uurloon in het Hoger Onderwijs zelfs net iets hoger dan in de andere sectoren. Het verschil in beloning is met name groot voor afgestudeerden met een technische of medische opleidingsachtergrond. Opmerkelijk genoeg verdienen degenen met een technische opleiding in het Hoger Onderwijs het laagste gemiddelde bruto uurloon. De tabel laat overigens ook duidelijk zien dat de beloningsverschillen tussen de diverse studierichtingen in het Hoger Onderwijs veel kleiner zijn dan in de andere sectoren. Dit zou erop kunnen wijzen dat minder goed wordt ingespeeld op de feitelijke arbeidsmarktsituatie op het segment waarop men personeel werft. 
Tabel 4.2

Gemiddelde bruto uurionen van recent afgestudeerde WO-ers naar opleidingsachtergrond, 1998

\begin{tabular}{|c|c|c|c|}
\hline \multirow[t]{2}{*}{ Opleiding } & \multicolumn{2}{|c|}{ Hoger onderwijs } & \multirow{2}{*}{$\begin{array}{l}\text { Overige sectoren } \\
\text { guldens }\end{array}$} \\
\hline & $\begin{array}{l}\text { excl. AlO's } \\
\text { guldens }\end{array}$ & $\begin{array}{l}\text { AlO's } \\
\text { guldens }\end{array}$ & \\
\hline $\begin{array}{l}\text { Landbouw en natuurlijke omgeving } \\
\text { Techniek } \\
\text { Economie } \\
\text { Gezondheid } \\
\text { Gedrag en maatschappij } \\
\text { Taal en cultuur } \\
\text { Recht } \\
\text { Natuur }\end{array}$ & $\begin{array}{l}23,90 \\
21,40 \\
25,50 \\
25,40 \\
26,20 \\
25,20 \\
23,70 \\
23,30\end{array}$ & $\begin{array}{l}14,70 \\
17,80 \\
15,60 \\
15,70 \\
15,40 \\
14,50 \\
- \\
14,40\end{array}$ & $\begin{array}{l}24,40 \\
26,90 \\
27,60 \\
31,70 \\
26,50 \\
24,60 \\
25,50 \\
26,00\end{array}$ \\
\hline Totaal & 24,30 & $15,3.0$ & 26,80 \\
\hline
\end{tabular}

"-" te weinig waarnemingen

\subsection{Werkzekerheid}

De aard van de aanstelling geeft een indicatie van de werkzekerheid in een bepaalde sector. In tabel 4.3 is een overzicht gegeven van het percentage afgestudeerde academici met een flexibele aanstelling. Een functie wordt als flexibel aangemerkt wanneer het een aanstelling via een uitzendbureau of een aanstelling als oproepkracht betreft, dan wel wanneer het een aanstelling in tijdelijke dienst is voor maximaal één jaar. Aangezien AlO's/OlO's over het algemeen een contract van vier jaar of langer hebben is deze groep in de tabel buiten beschouwing gelaten.

Tabel 4.3

Percentage recent afgestudeerde WO-ers met een flexibele aanstelling, 1998

\begin{tabular}{lcc}
\hline Opleiding & Hoger onderwijs & Overige sectoren \\
& excl. AlO's \\
& $\%$ & $\%$ \\
\hline & & \\
Landbouw en natuurlijke omgeving & 23 & 17 \\
Techniek & 6 & 6 \\
Economie & 12 & 5 \\
Gezondheid & 15 & 14 \\
Gedrag en maatschappij & 24 & 18 \\
Taal en cultuur & 45 & 25 \\
Recht & 31 & 11 \\
Natuur & 26 & 15 \\
\end{tabular}

Uit de tabel komt naar voren dat afgestudeerden die werkzaam zijn in het Hoger Onderwijs over het algemeen vaker een flexibele aanstelling hebben dan hun studiegenoten die werkzaam zijn in een andere sector. Het verschil tussen het Hoger Onderwijs en de andere sectoren is vooral groot voor afgestudeerden met een opleidingachtergrond Economie, Taal \& Cultuur, Recht en Natuur. Dit hoge percentage 
flexibele aanstellingen kan de concurrentiepositie van het Hoger Onderwijs verzwakken, voor zover het werken in deze sector hierdoor minder aantrekkelijk wordt.

\subsection{Kwaliteit van het werk}

De aansluiting tussen de huidige functie en de gevolgde opleiding geeft een belangrijke indicatie van de kwaliteit van het werk. Dit geldt zowel voor het niveau van het werk, als de mate waarin de aard van het werk aansluit bij de gevolgde opleiding. Tabel 4.4 laat het percentage afgestudeerden zien waarvan de huidige functie in dezelfde of een aanverwante richting van de gevolgde opleiding ligt. Zowel AIO's/OIO's als de andere academici werkzaam in het Hoger Onderwijs geven vaker aan in de eigen of een daaraan verwante richting te werken dan degenen die werkzaam zijn in andere bedrijfssectoren. Op dit punt is de concurrentiepositie van de sector Hoger Onderwijs ten opzichte van de andere sectoren derhalve sterk. Vooral in de studierichting Taal \& Cultuur is het verschil op dit punt erg groot. Slechts $43 \%$ van de afgestudeerden die werkzaam zijn buiten het Hoger Ondenwijs heeft een functie die aansluit bij de gevolgde studierichting, tegenover driekwart van degenen die werkzaam zijn in het Hoger Onderwijs.

Tabel 4.5 geeft een overzicht van het niveau van het werk. Hierbij gaat het om het percentage academici dat werkzaam is op WO-niveau. Ook op dit punt hebben degenen die zijn gaan werken in het Hoger Onderwijs duidelijk een betere positie dan degenen die werkzaam zijn in andere sectoren. Recent afgestudeerden die werkzaam zijn binnen het Hoger Onderwijs hebben veel vaker een baan op WOniveau dan afgestudeerden die buiten deze sector werkzaam zijn. Op dit punt steekt de concurrentiepositie van het Hoger Onderwijs dan ook weer beter af tegen die van de andere sectoren. De afgestudeerden in de HOOP-sector Gezondheid vormen hierop echter een uitzondering.

Tabel 4.4

Recent afgestudeerden WO-ers werkzaam in de eigen of een daaraan verwante richting naar opleidingsachtergrond, 1998

\begin{tabular}{lccc}
\hline Opleiding & \multicolumn{2}{c}{ Hoger onderwijs } & Overige sectoren \\
& $\begin{array}{c}\text { excl. AlO's } \\
\%\end{array}$ & $\begin{array}{c}\text { AlO's } \\
\%\end{array}$ & $\%$ \\
\hline Landbouw en natuurlijke omgeving & 85 & 92 & 72 \\
Techniek & 85 & 96 & 76 \\
Economie & 93 & 96 & 75 \\
Gezondheid & 100 & 92 & 95 \\
Gedrag en maatschappij & 74 & 94 & 59 \\
Taal en cultuur & 84 & 94 & 43 \\
Recht & 88 & - & 79 \\
Natuur & 82 & 97 & 73 \\
\hline "-"teweing & & & \\
\hline
\end{tabular}

"-" te weinig waarnemingen

Het oordeel van recent afgestudeerden over de aansluiting van hun huidige functie bij de gevolgde opleiding geeft ook een indicatie van de (inhoudelijke) kwaliteit van 
het werk. Tabel 4.6 presenteert het percentage afgestudeerden dat de aansluiting tussen de gevolgde opleiding en de huidige functie voldoende tot goed vindt. De aansluiting wordt met name door AlO's/OIO's, vaker positief beoordeeld, dar, door degenen die buiten het Hoger Onderwijs werkzaam zijn. Bij de anderen die werkzaam zijn in het Hoger Onderwijs is het percentage dat de aansluiting tussen werk en opleiding voldoende tot goed vindt echter niet veel groter dan bij degenen die elders werkzaam zijn.

Tabel 4.5

Recent afgestudeerde WOers werkzaam op eigen niveau naar opleidingsachtergrond, 1998

Opleiding

$\begin{array}{cc}\text { Hoger onderwijs } & \text { Overige sectoren } \\ \text { excl. AlO's* } \\ \%\end{array} \quad \%$

Landbouw en natuurlijke omgeving

Techniek

Economie

Gezondheid

Gedrag en maatschappij

Taal en cultuur

Recht

Natuur

$\begin{array}{ll}94 & 53 \\ 90 & 62 \\ 94 & 56 \\ 86 & 90 \\ 82 & 47 \\ 73 & 36 \\ 94 & 75 \\ 87 & 58\end{array}$

" AIO's/OIO's werken altijd op WO niveau

Tabel 4.6

Percentage recent afgestudeerde WO-ers die de aansluiting tussen huidige functie en opleiding voldoende tot goed vindt, 1998

\begin{tabular}{lccc} 
Opleiding* & \multicolumn{2}{c}{ Hoger onderwijs } & Overige sectoren \\
& $\begin{array}{c}\text { excl. AlO's } \\
\%\end{array}$ & $\begin{array}{c}\text { AlO's } \\
\%\end{array}$ & $\%$ \\
\hline Landbouw en natuurlijke omgeving & 99 & 100 & 81 \\
Techniek & 100 & 97 & 86 \\
Economie & 88 & 100 & 89 \\
Gezondheid & 94 & 96 & 88 \\
Gedrag en maatschappij & 80 & 100 & 69 \\
Taal en cultuur & 65 & 100 & 60 \\
Recht & -5 & - & 84 \\
Natuur & 88 & 96 & 83
\end{tabular}

"Decijfers in deze tabel hebben betrekking op 10 van de in totaal 13 universiteiten

"-" te weinig waarnemingen

\subsection{Tevredenheid recent afgestudeerden}

Een algemeen beeld van de waardering van de betrokkenen voor het werk dat men uitoefent, wordt gegeven door de mate van 'tevredenheid'. AlO's/OIO's zijn op dit punt veel positiever dan recent afgestudeerden die werkzaam zijn in andere functies binnen het Hoger Onderwijs en degenen die elders werkzaam zijn. Met uitzondering van afgestudeerden in de HOOP-sectoren Gezondheid en Taal \& Cultuur, zijn de 
werkenden binnen het Hoger Onderwijs die niet werkzaam zijn als AIO, ook vaker tevreden over hun huidige functie dan degenen die in andere bedrijfssectoren werkzaam zijn.

Tabel 4.7

Percentage recent afgestudeerde WO-ers dat tevreden tot zeer tevreden is over de huidige functie, 1998

\begin{tabular}{|c|c|c|c|}
\hline \multirow[t]{2}{*}{ Opleiding* } & \multicolumn{2}{|c|}{ Hoger onderwijs } & \multirow{2}{*}{$\begin{array}{c}\text { Overige sectoren } \\
\%\end{array}$} \\
\hline & $\underset{\%}{\operatorname{excl} . \text { AlO's }}$ & $\begin{array}{c}\text { AlO's } \\
\%\end{array}$ & \\
\hline $\begin{array}{l}\text { Landbouw en natuurlijke omgeving } \\
\text { Techniek } \\
\text { Economie } \\
\text { Gezondheid } \\
\text { Gedrag en maatschappij } \\
\text { Taal en cultuur } \\
\text { Recht } \\
\text { Natuur }\end{array}$ & $\begin{array}{r}80 \\
78 \\
66 \\
77 \\
56 \\
100\end{array}$ & $\begin{array}{l}83 \\
95 \\
91 \\
97 \\
95 \\
91\end{array}$ & $\begin{array}{l}- \\
75 \\
76 \\
77 \\
67 \\
68 \\
73 \\
80\end{array}$ \\
\hline
\end{tabular}

N.B. De data hebben betrekking op 9 universiteiten

"-" te weinig waarnemingen

Tabel 4.8

Percentage recent afgestudeerde WO-ers opzoek naar een andere baan, 1998

\begin{tabular}{lccc}
\hline Opleiding & Hoger onderwijs & Overige sectoren \\
\multicolumn{1}{c}{$\%$} & \multicolumn{2}{c}{$\begin{array}{c}\text { excl. AlO's } \\
\%\end{array}$} & $\begin{array}{c}\text { AlO's } \\
\%\end{array}$ \\
\hline & & & \\
Landbouw en natuurlijke omgeving & 36 & 7 & 29 \\
Techniek & 19 & 12 & 17 \\
Economie & 18 & 19 & 17 \\
Gezondheid & 33 & 12 & 37 \\
Gedrag en maatschappij & 36 & 18 & 38 \\
Taal en cultuur & 50 & 21 & 31 \\
Recht & 48 & 40 & 36 \\
Natuur & 25 & & \\
\hline
\end{tabular}

\subsection{Belangrijke baankenmerken}

De figuren 4.3 en 4.4 geven ten slotte een overzicht van het belang dat recent afgestudeerden hechten aan bepaalde baankenmerken en de mate waarop ze vinden dat ze die in hun huidige functie kunnen realiseren.

Degenen die werkzaam zijn in het Hoger Onderwijs blijken het inkomen dat men verdient minder belangrijk te vinden dan degenen die elders werkzaam zijn. Dit wijst er nogmaals op dat het Hoger Onderwijs voornamelijk afgestudeerden aantrekt die met name belang hechten aan de inhoud van het werk. Figuur 4.4 laat echter zien dat degenen die niet werkzaam zijn in het Hoger Onderwijs op punten als 'verantwoordelijkheid' en 'afwisseling' hun huidige functie vaker positief beoordelen dan 
degenen die werkzaam zijn in het Hoger Onderwijs. De AlO/OIO functies blijken, zoals verwacht mag worden, het hoogst te scoren op punten als 'ontwikkelingexpertise', 'uitdaging' en 'creativiteit'. Degenen die in het Hoger Onderwijs in andere functies werkzaam zijn beoordelen de inhoud van hun baan echter op vrijwel geen enkel punt duidelijk positiever dan degenen die elders werkzaam zijn. Dit geeft aan dat de concurrentiepositie van het Hoger Onderwijs op de arbeidsmarkt ook op het punt van de inhoud van het werk mogelijk minder sterk is dan op basis van de aansluiting tussen functie en opleiding verwacht mocht worden.

\section{Figuur 4.3}

Percentage recent afgestudeerde WO-ers dat de onderstaande baankenmerken belangrijk tot zeer belangrijk vindt*, 1998

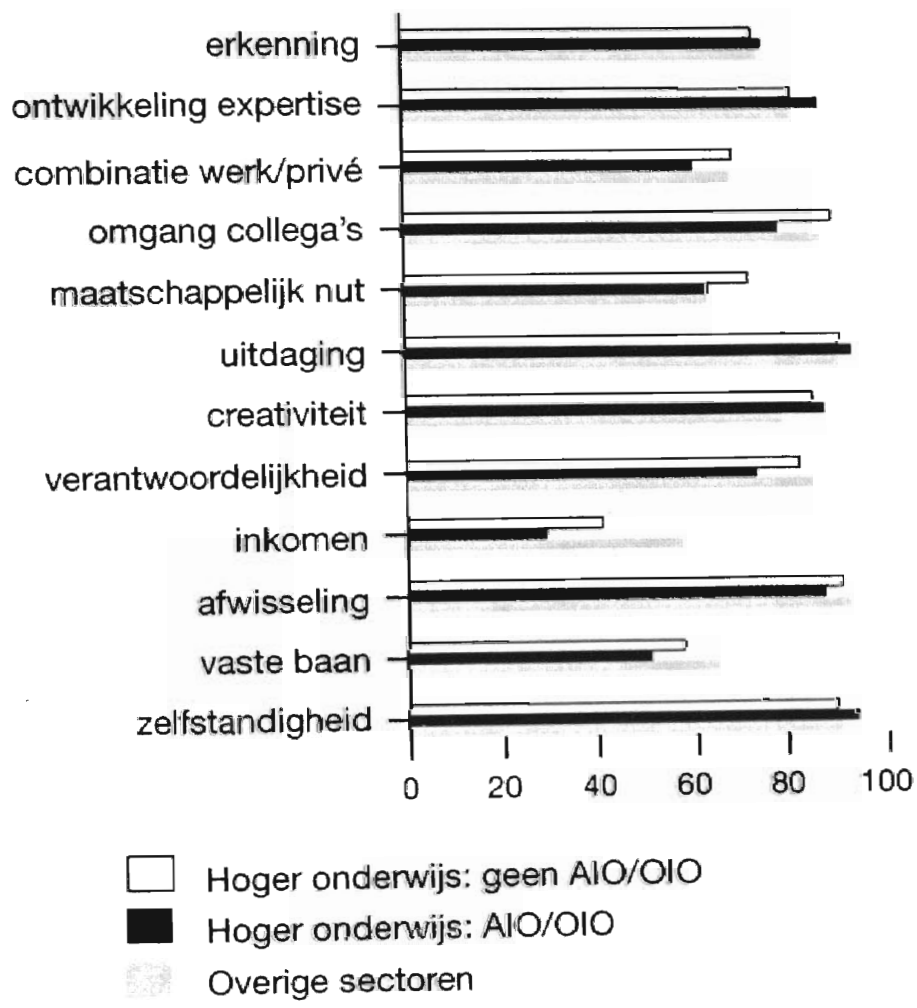

- de data hebben betrekking op 10 universiteiten 


\section{Figuur 4.4}

Percentage recent afgestudieerde WO-ers dat de onderstaande baankenmerken in sterke mate kan realiseren in de huidige functie, 1998

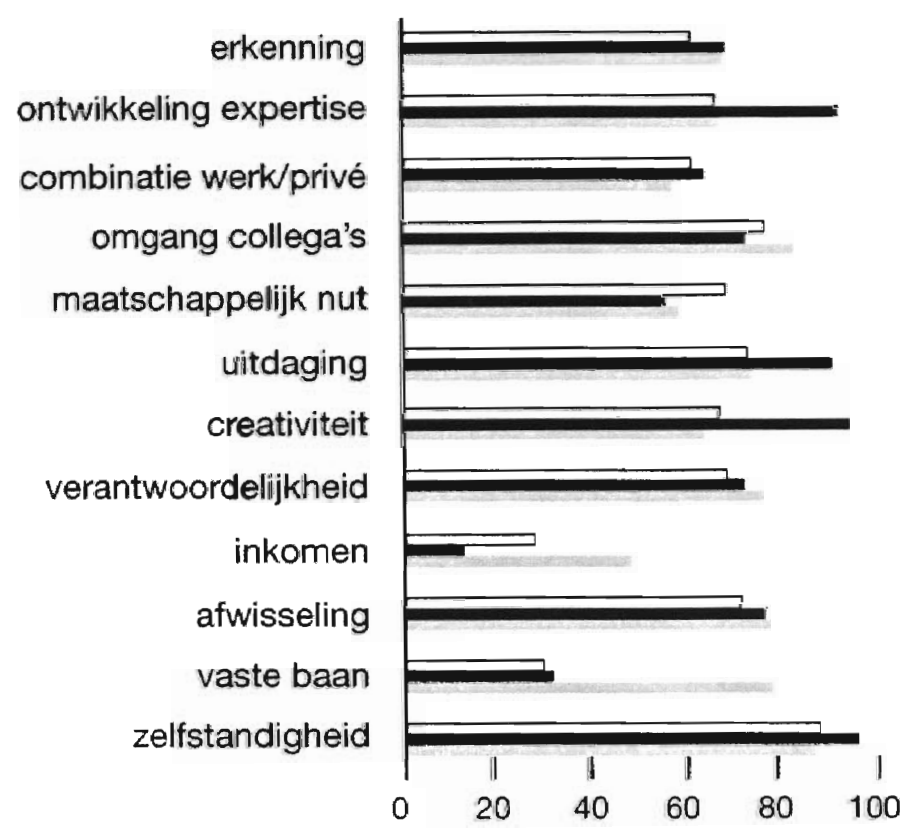

Hoger onderwijs: geen $\mathrm{AlO} / \mathrm{OIO}$

Hoger onderwijs: AIO/OIO

Overige sectoren

\subsection{Positieve of negatieve keuze?}

De werkgelegenheidsperspectieven van afgestudeerden zijn het afgelopen jaar in bijna alle opleidings- en bedrijfssectoren ronduit rooskleurig te noemen. Deze positieve ontwikkeling uit zich onder andere in een korte duur van de intredewerkloosheid in de transitiefase van studie naar werk. Tabel 4.9 geeft een overzicht van deze intredewerkloosheid naar opleidingsachtergrond. Opvallend is dat AIO's/ OIO's na hun afstuderen relatief kort werkloos zijn geweest. Dit is met name het geval bij de afgestudeerden in de richtingen Techniek, Economie en Gezondheid. Voor de laatste twee opleidingsrichtingen geldt zelfs dat bijna geen van de AIO's/ OIO's na hun afstuderen langer dan 4 maanden werkloos is geweest. Dit wijst op 
een positieve selectie. Voor afgestudeerden Recht geldt daarentegen dat een relatief hoog percentage, maar liefst $23 \%$, langer dan 4 maanden werkioos is geweest. Dit wijst op een negatieve selectie. Slechts wanneer men geen baan als jurist buiten het Hoger Onderwijs kan vinden, besluit men om een AlO functie te accepteren. Wanneer AIO's/OIO's buiten beschouwing worden gelaten vertoont de sector Hoger Onderwijs min of meer hetzelfde patroon als de overige sectoren waarin academici werkzaam zijn.

\section{Tabel 4.9}

Intredewerkloosheid van meer dan 4 maanden van recent afgestudeerde WO-ers naar opleidingsachtergrond, 1998

\begin{tabular}{lccc}
\hline Opleiding & \multicolumn{2}{c}{ Hoger onderwijs } & Overige sectoren \\
& $\begin{array}{c}\text { excl. AlO's } \\
\%\end{array}$ & $\begin{array}{c}\text { AlO's } \\
\%\end{array}$ & $\%$ \\
\hline Landbouw en natuurlijke omgeving & 13 & 10 & 15 \\
Techniek & 10 & 3 & 14 \\
Economie & 11 & 0 & 9 \\
Gezondheid & 6 & 0 & 14 \\
Gedrag en maatschappij & 15 & 12 & 11 \\
Taal en cultuur & 14 & 5 & 11 \\
Recht & 10 & 23 & 11 \\
Natuur & 11 & 6 & \\
\hline
\end{tabular}

Dit wijst erop dat het Hoger Onderwijs bij het aantrekken van recent afgestudeerden geen genoegen hoeft te nemen met degenen die niet snel een baan elders kunnen vinden. Het is echter ook niet zo dat de instellingen voor het Hoger Onderwijs er 'sneller bij zij' dan de werkgevers in de overige sectoren. 


\section{Besluit}

\subsection{Conclusie}

Met uitzondering van de opleidingen WO landbouw en milieukunde, WO farmacie en WO kunstwetenschappen worden voor alle WO opleidingstypen de komende jaren grote knelpunten in de personeelsvoorziening verwacht. Bij WO accountancy en belastingen, WO informatica en bestuurlijke informatiekunde, WO econom(etr)ie en WO bedrijfskunde kan zelfs gesproken worden van zeer grote knelpunten. Bij een aantal opleidingen zijn deze knelpunten voomamelijk toe te schrijven aan een sterke groei van de werkgelegenheid. Dit geldt vooral voor de informatici, economen en bedrijfskundigen. Bij enkele technische opleidingen en de opleiding tandheelkunde waar de vergrijzing veel verder is voortgeschreden dan bij andere WO-opleidingstypen, zijn de verwachte arbeidsmarktknelpunten vooral toe te schrijven aan de naar verwachting hoge vervangingsvraag. Bij WO elektrotechniek, WO theologie en de medische opleidingen zijn de verwachte knelpunten vooral het gevolg van de relatief lage arbeidsmarktinstroom van afgestudeerden. Met name bij de medische opleidingen is dit opmerkelijk, gezien de 'arbeidsmarkt fixus' die bij de toelating van deze opleidingen wordt gehanteerd.

Daar er voornamelijk universitair opgeleiden als docent werkzaam zijn in het Hoger Onderwijs betekent dit dat hogescholen en universiteiten bij de werving van personeel in toenemende mate met problemen te kampen kunnen krijgen. Dit geldt temeer daar het Hoger Onderwijs vanwege de relatief grote groep oudere docenten die de komende jaren de arbeidsmarkt zal verlaten, in toenemende mate nieuw personeel moet aantrekken om in de vervangingsvraag te voorzien. Dit komt tot uiting in de vervangingsbehoefte die voor het HBO in de periode 1999-2004 circa 9,0\% bedraagt en voor het WO maar liefst $15,1 \%$. Daarentegen zal de werkgelegenheid in het $\mathrm{HBO}$ de komende vijf jaar met 2,3\% afnemen. Echter, indien de door de HBOraad gebrachte cijfers over het aantal studenten gehaald worden, dan zal de werkgelegenheid in het HBO de komende jaren juist zeer sterk toenemen. In het WO zal de werkgelegenheid voor docenten naar verwachting licht toenemen. De lichte toename in het aantal studenten geldt echter niet voor alle WO-opleidingen. Onderverdeeld naar HOOP-sectoren laten de meeste sectoren zelfs een daling zien. De werkgelegenheidsgroei concentreert zich in de HOOP-sectoren Techniek en Economie. Vooral in deze sectoren zullen derhalve veel extra docenten moeten worden aangetrokken.

Gezien de spilfunctie die de docenten in het Hoger Onderwijs vervullen voor de kennisoverdracht in de Nederlandse samenleving, is een tekort aan docenten in deze sector zeer zorgwekkend voor het toekomstige niveau van de onderwijskwaliteit. Dit kan derhalve een belangrijke hinderpaal vormen voor de voortschrijdende ontwikkeling van de Nederlandse samenleving in de richting van een kennisintensieve economie. 
In de huidige samenleving is er in vrijwel alle bedrijfssectoren vraag naar universitair opgeleiden. Tussen de verscheidene sectoren is het verschil echter aanzienlijk. Ruim $7 \%$ van de werkende beroepsbevolking, dat betreft 475.000 personen, heeft een universitaire opleidingsachtergrond. Hiervan werken er 80.000 in het onderwijs en 47.600 in het Hoger Onderwijs; dit is goed voor een marktaandeel van $10,1 \%$.

Voor het Hoger Onderwijs is de markt voor recent afgestudeerde academici een belangrijk segment om docenten te werven. Om de aantrekkelijkheid van het werken in het Hoger Onderwijs in kaart te brengen is de concurrentiepositie die de instellingen voor het Hoger Onderwijs op de arbeidsmarkt innemen in kaart gebracht. Hiervoor zijn een viertal indicatoren voor gebruikt:

- beloning;

- werkzekerheid;

- kwaliteit van het werk;

- tevredenheid met huidige functie.

Recent afgestudeerden die werkzaam zijn in het Hoger Onderwijs verdienen minder dan hun werkende jaargenoten buiten deze sector. Het verschil in beloning is met name groot voor afgestudeerden met een technische of medische opleidingsachtergrond. Opmerkelijk genoeg verdienen degenen met een technische opleiding in het Hoger Onderwijs het laagste gemiddelde bruto uurloon. De beloningsverschillen tussen de diverse studierichtingen in het Hoger Onderwijs zijn echter veel kleiner dan in de andere sectoren. Dit zou erop kunnen wijzen dat minder goed wordt ingespeeld op de feitelijke arbeidsmarktsituatie op het segment waarop men personeel werft.

Ook hebben recent afgestudeerden vaker een flexibel contract, terwijl een vaste baan wel belangrijk wordt gevonden. Op het punt van de kwaliteit van het werk scoort het Hoger Onderwijs beter dan de andere sectoren. Zo zijn recent afgestudeerden vaker werkzaam op het eigen niveau dan hun jaargenoten die werkzaam zijn buiten het Hoger Onderwijs. Tevens zijn zij ook vaker werkzaam in de eigen of een daaraan verwante richting naar opleidingsachtergrond. Tenslotte is het percentage recent afgestudeerden dat de aansluiting tussen hun opleiding en hun huidige functie voldoende tot goed vindt hoger bij degenen die werkzaam zijn in het Hoger Onderwijs dan in de rest van de sectoren.

Er is ook nagegaan in hoeverre recent afgestudeerden in het Hoger Onderwijs tevreden zijn met hun huidige functie in vergelijking met jaargenoten in de andere sectoren. Hieruit blijkt dat dit percentage hoger ligt in het Hoger Onderwijs dan in de overige sectoren. Een indirecte indicator met betrekking tot tevredenheid is het percentage recent afgestudeerden dat op zoek is naar een andere baan. Van degenen die werkzaam zijn in het HBO of WO is een geringer deel op zoek naar een andere baan dan in de overige sectoren.

Opvallend is dat AIO's/OIO's na hun afstuderen relatief kort werkloos zijn geweest. Dit is met name het geval bij de afgestudeerden in de richtingen Techniek, 
Economie en Gezondheid. Voor de laatste twee opleidingsrichtingen geldt zelfs dat bijna geen van de AIO's/OIO's na hun afstuderen langer dan 4 maanden werkloos is geweest. Dit wijst op een positieve selectie. Voor afgestudeerden Recht geldt daarentegen dat een relatief hoog percentage, maar liefst $23 \%$, langer dan 4 maanden werkloos is geweest. Dit wijst op een negatieve selectie.

Concluderend kan gesteld worden dat de lagere beloning en de geringere werkgelegenheid de concurrentiepositie vezwakt.

\subsection{Beleidsimplicaties}

Om voor de komende jaren verzekerd te zijn van voldoende docenten in het Hoger Onderwijs is het verstandig om op dit punt preventief beleid te voeren. Daarbij zouden de volgende vier punten centraal kunnen staan:

1. terugdringen van de uitstroom uit het Hoger Onderwijs;

2. doorstroming van aio's naar docentfuncties;

3. doorgroei van vrouwen;

4. het aantrekken van meer nieuwkomers.

In het HBO is de totale uitstroom hoger dan de uitstroom die op basis van de vergrijzing mag worden verwacht. Dit betekent dat jongere docenten reeds voor het bereiken van de pensioen- c.q. VUT-gerechtigde leeftijd het HBO verlaten. Het vroegtijdig uitstromen van docenten in het Hoger Onderwijs kan verschillende oorzaken hebben. Een belangrijke reden kan zijn dat een functie in een andere sector op bepaalde punten aantrekkelijker is. In het vorige hoofdstuk is de concurrentiepositie van het Hoger Onderwijs aan bod gekomen. Hieruit kwam naar voren dat het Hoger Onderwijs op bijna alle punten, behalve de primaire arbeidsvoorwaarden, minstens even goed als de overige sectoren. In de sfeer van de primaire arbeidsvoorwaarden zou gedacht kunnen worden aan het bieden van een hogere 'marktconforme' beloning en het sneller aanbieden van een vast contract.

AIO's worden thans aangenomen voor de duur van maximaal 4 jaar waarin zij hun proefschrift schrijven. Naast het schrijven van dit proefschrift vormt het geven van onderwijs vaak een belangrijk gedeelte van het werk. Na de promotie veriaten de meeste, al dan niet vrijwillig, de universiteit. Rector Magnificus Nieuwenhuijzen Kruseman van de Universiteit Maastricht merkt in zijn recente diesrede dan ook op dat naast het lage salaris het gebrekkige carrière perspectief waarschijnlijk een belangrijke zo niet belangrijkere reden is voor de dalende belangstelling voor een AIO-aanstelling ${ }^{16}$. Dit terwijl AIO's zo hard nodig zijn, niet alleen voor het onderzoek maar zeer zeker ook voor het onderwijs. Echter de laatste jaren is gebleken dat het steeds moeilijker wordt om afgestudeerden te vinden die tegen een zeer lage beloning een proefschrift willen schrijven. Wanneer AIO's na hun promotie een beter

16. A.C Nieuwenhuijzen Kruseman, Wetenschap blift Mensenwerk, uit Redes gehouden tijdens de opening van het Academisch Jaar 1999/2000 op 6 september 1999 en de $24 e$ Dies Natalis op 7 januari 2000, Maastricht 2000. 
loopbaanperspectief binnen de universiteit zou worden aangeboden, zal ook de aantrekkelijkheid van een $\mathrm{AlO}$-functie waarschijnlijk, worden vergroot.

In het Hoger Onderwijs is circa een derde deel van de werkenden vrouw ${ }^{17}$. Vanaf 1993 is er wel sprake van een lichte stijging van het werkgelegenheidsaandeel van vrouwen in het Hoger Onderwijs. Voor zowel het $\mathrm{HBO}$ als het WO geldt dat het aandeel vrouwen per functie aanzienlijk verschilt. Het grootste percentage vrouwen is werkzaam in de ondersteunende beroepen en de lagere wetenschappelijke functies. Door meer vrouwen door te laten groeien naar hogere functies, zullen vrouwen mogelijk minder snel geneigd zijn om het Hoger Onderwijs te verlaten.

Ten slotte is het verhogen van de arbeidsmarktinstroom in het Hoger Onderwijs ook een belangrijke optie om de tekorten aan docenten op te lossen. Om deze instroom te verhogen kan getracht worden om de beeldvorming over het werken in het Hoger Onderwijs te verbeteren. Daarbij zou vooral kunnen worden gewezen op de relatief aantrekkelijke baankenmerken van de functies in het Hoger Onderwijs, zoals de hoge mate van zelfstandigheid, goede combinatie werk-privè, het maatschappelijk nut en creativiteit.

Nieuwe werknemers kunnen uit twee groepen worden geworven: de recent afgestudeerden en afgestudeerden die reeds elders werkzaam. De groep recent afgestudeerden kunnen reeds tijdens hun studie worden benaderd. Door het mogelijk te maken om het werken in het Hoger Onderwijs te combineren met werkzaamheden buiten de sector, kunnen mogelijk ook docenten worden aangetrokkenen waarvoor deze combinatie interessant is. Voor het HBO bestaat ook de mogelijkheid om leraren die les geven in het secundair onderwijs aan te trekken. Een deel van hen heeft immers na een aantal jaren de wens om door te stromen naar het Hoger Beroepsonderwijs waar ze met oudere leerlinge/studenten kunnen werken.

17. Sectorbestuur voor de Onderwijsarbeidsmarkt, De onderwijsarbeidsmarkt in beeld, SBO jaarboek 1999, Den Haag, 1999. 


\section{Bijlage: Achtergrondtabellen}

Tabel B.1

Aantal werkenden per bedrijfssector naar werktijd, gemiddelde 1997-1998

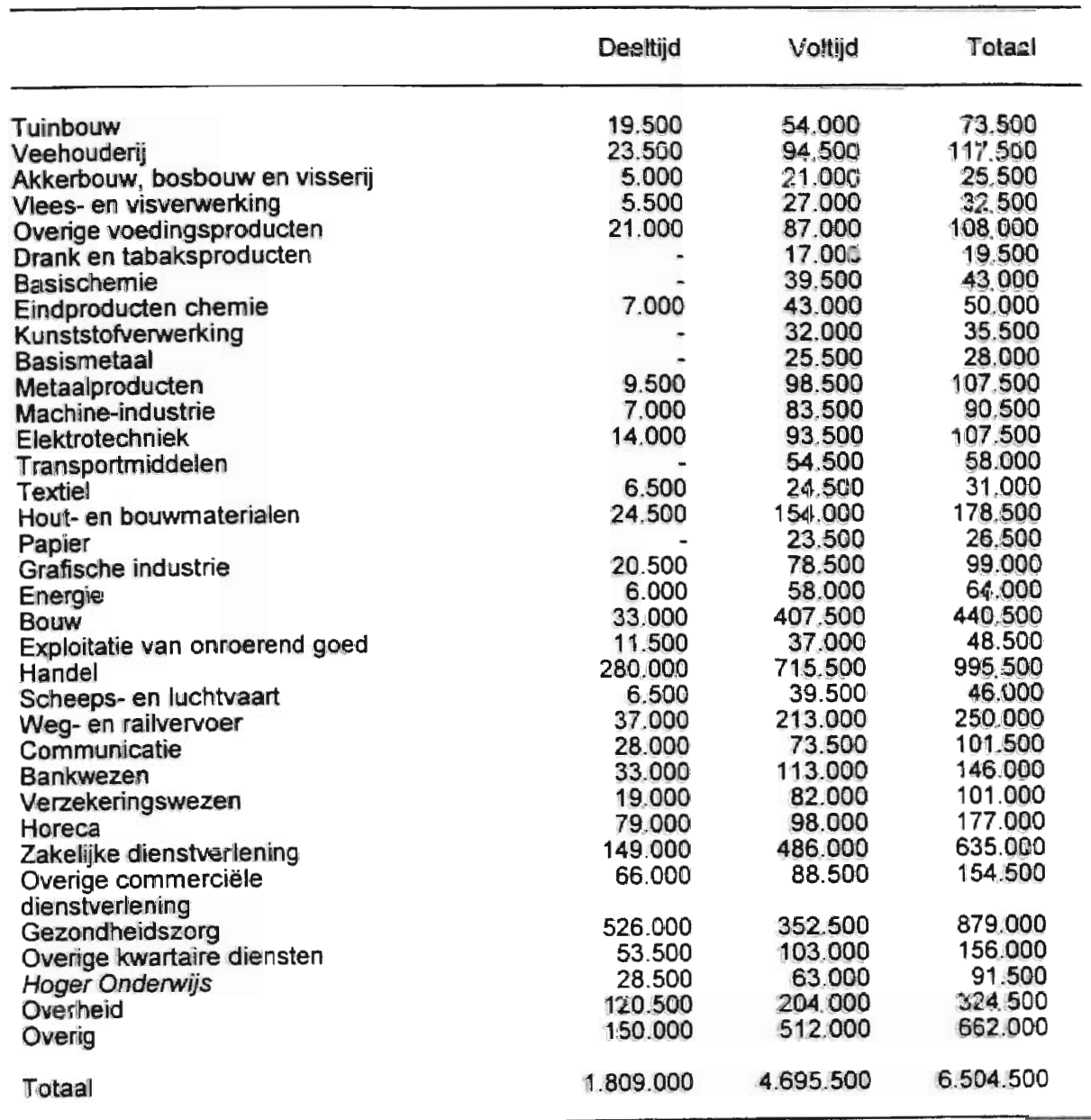

Bron: CBS/ROA 
Tabel B.2

Aantal werkenden per bedrijfssector naar aard van de aanstelling, gemiddelde 1997-1998

\begin{tabular}{|c|c|c|c|}
\hline & Vast & Flexibel & Zelfstandig \\
\hline $\begin{array}{l}\text { Tuinbouw } \\
\text { Veehouderij } \\
\text { Akkerbouw, bosbouw en visserij }\end{array}$ & $\begin{array}{l}32.500 \\
29.500\end{array}$ & $\begin{array}{r}11.500 \\
6.000 \\
\end{array}$ & $\begin{array}{l}29.500 \\
82.000 \\
19.500\end{array}$ \\
\hline & 25.500 & 6.000 & \\
\hline $\begin{array}{l}\text { Overige voedingsproducten } \\
\text { Drank en tabaksproducten }\end{array}$ & $\begin{array}{l}88.000 \\
17.500\end{array}$ & 12.000 & 8.500 \\
\hline Basischemie & 40.000 & - & - \\
\hline Eindproducten chemie & 46.500 & - & - \\
\hline Kunststofverwerking & 31.500 & - & - \\
\hline Basismetaal & 26.000 & - & - \\
\hline Metaalproducten & 92.500 & 8.000 & 7.000 \\
\hline Machine-industrie & 83.000 & 5.000 & - \\
\hline Elektrotechniek & 96.500 & 9.000 & - \\
\hline Transportmiddelen & 50.500 & 6.000 & - \\
\hline Textiel & 22.500 & & \\
\hline $\begin{array}{l}\text { Hout- en bouwmaterialen } \\
\text { Panier }\end{array}$ & 157.000 & 11.500 & 10.000 \\
\hline $\begin{array}{l}\text { Papier } \\
\text { Grafische industrie }\end{array}$ & $\begin{array}{l}24.000 \\
83.500\end{array}$ & $7.000^{-}$ & $8.500^{-}$ \\
\hline Energie & 60.500 & & \\
\hline $\begin{array}{l}\text { Bouw } \\
\text { Exploitatie yan onroerend goed }\end{array}$ & 359.000 & 20.500 & 61.000 \\
\hline $\begin{array}{l}\text { Exploitatie van onroerend goed } \\
\text { Handel }\end{array}$ & $\begin{array}{r}41.000 \\
765.500\end{array}$ & 88.500 & $\begin{array}{r}5.500 \\
141.000\end{array}$ \\
\hline Scheeps- en luchtvaart & 42.000 & & \\
\hline $\begin{array}{l}\text { Weg-en railvervoer } \\
\text { Communicatie }\end{array}$ & 209.500 & 23.500 & 17.000 \\
\hline $\begin{array}{l}\text { Communicatie } \\
\text { Bankwezen }\end{array}$ & $\begin{array}{r}86.500 \\
136.000\end{array}$ & $\begin{array}{r}12.500 \\
8.500\end{array}$ & - \\
\hline Verzekeringswezen & 86.000 & 6.500 & 8.000 \\
\hline Horeca & 100.500 & 41.000 & 35.500 \\
\hline Zakelijke dienstverlening & 480.000 & 51.500 & 103.500 \\
\hline Overige commerciële & 99.500 & 19.000 & 36.000 \\
\hline $\begin{array}{l}\text { diensiveriening } \\
\text { Gezondheidszorg }\end{array}$ & 734.000 & 89.500 & 55.500 \\
\hline Overige kwartaire diensten & 111.000 & 12.500 & 33.000 \\
\hline Hoger Onderwijs & 85.500 & 5.500 & \\
\hline Overheid & 289.000 & 22.500 & 13.000 \\
\hline Overig & 538.000 & 72.500 & 51.000 \\
\hline Totaal & 5.174 .000 & 585.000 & 745.500 \\
\hline
\end{tabular}

Bron: CBS/ROA 
Tabel B.3

Aanta! werkenden per bedrijfssectoren naar leeftijd, gemiddelde 1997-1998

\begin{tabular}{|c|c|c|c|}
\hline & $\begin{array}{r}15-29 \\
\text { jaar }\end{array}$ & $\begin{array}{c}\text { Leeftijd } \\
30-49 \\
\text { jaar }\end{array}$ & $\begin{array}{r}50-64 \\
\text { jaar }\end{array}$ \\
\hline $\begin{array}{l}\text { Tuinbouw } \\
\text { Veehouderij } \\
\text { Akkerbouw, bosbouw en visserij } \\
\text { Vlees- en visverwerking } \\
\text { Overige voedingsproducten } \\
\text { Drank en tabaksproducten } \\
\text { Basischemie } \\
\text { Eindproducten chemie } \\
\text { Kunststofverwerking } \\
\text { Basismetaal } \\
\text { Metaalproducten } \\
\text { Machine-industrie } \\
\text { Elektrotechniek } \\
\text { Transportmiddelen } \\
\text { Textiel } \\
\text { Hout- en bouwmaterialen } \\
\text { Papier } \\
\text { Grafische industrie } \\
\text { Energie } \\
\text { Bouw } \\
\text { Exploitatie van onroerend goed } \\
\text { Handel } \\
\text { Scheeps- en luchtvaart } \\
\text { Weg-en railvervoer } \\
\text { Communicatie } \\
\text { Bankwezen } \\
\text { Verzekeringswezen } \\
\text { Horeca } \\
\text { Zakelijke dienstverlening } \\
\text { Overige commerciële dienstverlening } \\
\text { Gezondheidszorg } \\
\text { Overige kwartaire diensten } \\
\text { Hoger Onderwijs } \\
\text { Overheid } \\
\text { Overig }\end{array}$ & $\begin{array}{r}22.500 \\
26.500 \\
5.500 \\
11.500 \\
32.500 \\
6.500 \\
11.000 \\
9.500 \\
32.500 \\
32.000 \\
26.500 \\
15.500 \\
8.500 \\
40.000 \\
6.500 \\
24.000 \\
7.500 \\
135.000 \\
11.000 \\
390.500 \\
11.000 \\
62.500 \\
25.000 \\
43.000 \\
28.500 \\
85.000 \\
204.500 \\
51.000 \\
209.000 \\
30.500 \\
16.000 \\
39.500 \\
140.500\end{array}$ & $\begin{array}{r}36.500 \\
57.000 \\
11.500 \\
17.000 \\
57.500 \\
12.500 \\
27.000 \\
31.000 \\
21.500 \\
17.500 \\
58.000 \\
50.500 \\
63.000 \\
32.500 \\
16.500 \\
103.000 \\
15.500 \\
58.500 \\
39.500 \\
236.000 \\
27.500 \\
463.000 \\
28.500 \\
142.000 \\
63.000 \\
85.500 \\
58.000 \\
72.000 \\
350.500 \\
78.500 \\
543.000 \\
93.500 \\
51.000 \\
195.500 \\
398.000\end{array}$ & $\begin{array}{r}15.000 \\
34.000 \\
8.500 \\
18.000 \\
9.500 \\
9.500 \\
7.500 \\
6.500 \\
17.500 \\
16.000 \\
18.000 \\
10.000 \\
6.500 \\
36.000 \\
17.000 \\
17.500 \\
69.500 \\
9.500 \\
141.500 \\
6.500 \\
45.500 \\
13.500 \\
17.000 \\
14.500 \\
19.500 \\
80.000 \\
25.000 \\
127.000 \\
32.000 \\
24.500 \\
89.500 \\
12.300\end{array}$ \\
\hline Totaal & 1.801 .500 & 3.612 .000 & 1.090 .500 \\
\hline
\end{tabular}

Bron: CBS/ ROA 
Tabel B.4

Leeftijdsopbouw wan de werkenden in het $\mathrm{HBO}, 1995-1998$

\begin{tabular}{lrrrr}
\hline Leeftijd & $\begin{array}{c}1995 \\
\%\end{array}$ & $\begin{array}{c}1996 \\
\%\end{array}$ & $\begin{array}{c}1997 \\
\%\end{array}$ & $\begin{array}{c}1998 \\
\%\end{array}$ \\
\hline$<25$ jaar & 1,4 & 1,4 & 1,5 & 1,6 \\
$25-29$ jaar & 6,6 & 5,9 & 5,9 & 5,6 \\
$30-34$ jaar & 10,6 & 9,6 & 9,4 & 12,8 \\
$35-39$ jaar & 15,1 & 13,7 & 13,8 & 17,5 \\
$40-44$ jaar & 18,7 & 18,4 & 17,7 & 20,3 \\
$45-49$ jaar & 22,6 & 22,3 & 20,7 & 20,2 \\
$50-54$ jaar & 15,4 & 17,6 & 18,9 & 10,5 \\
$55-59$ jaar & 7,9 & 8,8 & 9,7 & 2,6 \\
$60+$ jaar & 1,8 & 2,3 & 2,4 & \\
\hline
\end{tabular}

Bron: HBO-raad

Tabel B.5

Leeftijdsopbouw medewerkers WO naar fte's en aantallen personen per 31-12-'98

\begin{tabular}{lrr}
\hline Leeftijd & $\begin{array}{c}\text { Fte's } \\
\%\end{array}$ & $\begin{array}{c}\text { Personen } \\
\%\end{array}$ \\
\hline$<25$ jaar & 4,9 & 8,4 \\
$25-29$ jaar & 14,9 & 13,8 \\
$30-34$ jaar & 12,6 & 12,0 \\
$35-39$ jaar & 12,8 & 12,6 \\
$40-44$ jaar & 12,7 & 12,6 \\
$45-49$ jaar & 13,3 & 13,0 \\
$50-54$ jaar & 15,1 & 14,3 \\
$55-59$ jaar & 10,2 & 9,6 \\
$60-64$ jaar & 3,5 & 0,1 \\
$65+$ jaar & 0,1 & 52,400 \\
Totaal & 42,500 & \\
\hline
\end{tabular}

Bron: WOPI 
Tabel B. 6

Recent afgestudeerden WO-ers werkzaam in het Hoger Onderwijs naar opleidingsachtergrond, 1998

\begin{tabular}{lcc}
\hline Opleiding & Aantal & $\%$ \\
\hline Landbouw en natuurlijke omgeving & 136 & 7 \\
Techniek & 378 & 20 \\
Economie & 119 & 6 \\
Gezondheid & 110 & 6 \\
Gedrag en maatschappij & 320 & 17 \\
Taal en cultuur & 260 & 13 \\
Recht & 85 & 4 \\
Natuur & 528 & 27 \\
Totaal & 1936 & 100
\end{tabular}

Tabel B. 7

Aantal recent afgestudeerden WO-ers werkzaam in het Hoger Onderwijs naar opleidingsachtergrond, 1998

\begin{tabular}{lcc}
\hline Opleiding & $\begin{array}{c}\text { Hoger beroeps- } \\
\text { onderwijs }\end{array}$ & $\begin{array}{c}\text { Wetenschappelijk } \\
\text { onderwijs }\end{array}$ \\
\hline Landbouw en natuurlijke omgeving & 3 & 134 \\
Techniek & 4 & 373 \\
Economie & 9 & 110 \\
Gezondheid & 8 & 102 \\
Gedrag en maatschappij & 37 & 281 \\
Taal en cultuur & 39 & 219 \\
Recht & 2 & 82 \\
Natuur & 9 & 518 \\
\hline
\end{tabular}

